\title{
Armageddon and the Stock Market: US, Canadian and Mexican Market Responses to the 1962 Cuban Missile Crisis
}

\section{CAMA Working Paper 65/2020 July 2020}

\section{Richard K Burdekin}

Claremont McKenna College, Claremont, California

\section{Pierre L Siklos}

Wilfrid Laurier University, Waterloo, Ontario, Canada

Centre for Applied Macroeconomic Analysis, ANU

\begin{abstract}
The threat of nuclear annihilation has never been higher than in 1962, when US President Kennedy and Soviet Premier Khruschev engaged in brinkmanship over the placement of Soviet missiles in Cuba during October 16-28. Although the resolution of the crisis was followed by a sustained recovery in the US, Canadian and Mexican stock markets, the stock market impact of the crisis itself, at first glance, seems relatively limited. Notwithstanding the fact that empirical analysis of 1962 US market data reveal a significant break on October 23, 1962, which is the day after President Kennedy's television address about the Cuban missile crisis, the drop on this day was smaller than prior one day declines seen in the earlier part of the year. When we focus on the $1 \%$ left tail of the distribution, that is, just the very largest negative returns, a different story emerges, however. US uncertainty is now seen to have a significant negative impact on returns across each of the US, Canadian and Mexican markets. Moreover, the size of the negative response to the rise in uncertainty is comparable in all three cases notwithstanding the fact the pre-crisis Mexican stock market trajectory had been very different from that seen in the United States and Canada.
\end{abstract}




\title{
Keywords
}

Cuban Missile Crisis, Stock markets, Canada, Mexico, United States

\author{
JEL Classification
}

G15

\section{Address for correspondence:}

(E) cama.admin@anu.edu.au

ISSN 2206-0332

The Centre for Applied Macroeconomic Analysis in the Crawford School of Public Policy has been established to build strong links between professional macroeconomists. It provides a forum for quality macroeconomic research and discussion of policy issues between academia, government and the private sector.

The Crawford School of Public Policy is the Australian National University's public policy school, serving and influencing Australia, Asia and the Pacific through advanced policy research, graduate and executive education, and policy impact. 


\title{
Armageddon and the Stock Market: US, Canadian and Mexican Market Responses to the 1962 Cuban Missile Crisis*
}

\author{
RICHARD C. K. BURDEKIN and PIERRE L. SIKLOS \\ Claremont McKenna College, Claremont, California \\ Wilfrid Laurier University, Waterloo, Ontario, Canada \\ and Centre for Applied Macroeconomic Analysis
}

June 2020

\begin{abstract}
The threat of nuclear annihilation has never been higher than in 1962, when US President Kennedy and Soviet Premier Khruschev engaged in brinkmanship over the placement of Soviet missiles in Cuba during October 16-28. Although the resolution of the crisis was followed by a sustained recovery in the US, Canadian and Mexican stock markets, the stock market impact of the crisis itself, at first glance, seems relatively limited. Notwithstanding the fact that empirical analysis of 1962 US market data reveal a significant break on October 23, 1962, which is the day after President Kennedy's television address about the Cuban missile crisis, the drop on this day was smaller than prior one day declines seen in the earlier part of the year. When we focus on the $1 \%$ left tail of the distribution, that is, just the very largest negative returns, a different story emerges, however. US uncertainty is now seen to have a significant negative impact on returns across each of the US, Canadian and Mexican markets. Moreover, the size of the negative response to the rise in uncertainty is comparable in all three cases notwithstanding the fact the pre-crisis Mexican stock market trajectory had been very different from that seen in the United States and Canada.
\end{abstract}

Keywords: Cuban Missile Crisis; Stock markets; Canada; Mexico; United States JEL classification: $\mathrm{G} 15$ 
* The authors thank Sam Harrison, Jinyi Jiang, Xubin Shi and Yanjin Yang for excellent research assistance, kindly funded by the Financial Economics Institute at Claremont McKenna College. 
We will not prematurely or unnecessarily risk the costs of worldwide nuclear war in which even the fruits of victory would be ashes in our mouth - but neither will we shrink from that risk at any time it must be faced.

(President Kennedy, TV Address, October 22, 1962)

I doubt [the diplomatic way] is going to be successful. The other way is, I think, a combination of an air strike and probably invasion, which means that we would have to carry out both of those with the prospect that they [the missiles] might be fired.

(President Kennedy, Oval Office, October 26, 1962) ${ }^{1}$

\section{Introduction}

Although the record stock market drop associated with the United Kingdom's 2016 "Brexit" vote (Burdekin et al., 2018) was eclipsed in 2020 by the impact of the COVID-19 pandemic, neither the potential break-up of an economic union nor the global health crisis seemingly comes close to rivalling the threat of nuclear annihilation seen during October 16-28, 1962. At this time, US President Kennedy and Soviet Premier Khruschev engaged in ultimate stakes brinkmanship over the placement of Soviet missiles in Cuba, which Dixit and Skeath (1999, p. 457) characterize as a game of "chicken in real time." ${ }^{2}$ Nevertheless, the US market drop at this time was limited to around 7\%, leading McCrum (2018) to conclude that such a seemingly modest reaction implies that "the stock market isn't the best way to assess existential risk."

The overall October 1962 market reaction is subject to a number of qualifications, however. It is worth noting, as we shall see below, that the S\&P 500 had begun falling

\footnotetext{
${ }^{1}$ Quotation taken from May and Zelikow (1997, p. 476).

${ }^{2}$ See Kennedy (1968) for an insider perspective on the build-up of the crisis; while the recordings transcribed in May and Zelikow (1997) feature the actual words of many of the key players in the crisis.
} 
gradually soon after President Kennedy's inauguration. ${ }^{3}$ Leaked news on rising nuclear tensions and the Cuba situation may well have factored into the market drop seen earlier in 1962. Indeed, the trickle of 'bad' news began in January of that year when the Organization of American States expelled Cuba and soon followed up by imposing a trade embargo. News by the late summer of 1962 that the Soviet Union and Cuba had reached an arms agreement was itself preceded by the U.S. State department holding a briefing about an arms build-up in Cuba. As noted by Bloom (2009), the October 1962 crisis was still clearly associated with heightened market uncertainty, however, and the resolution of the crisis was immediately followed by a renewed uptrend not only in the United States but also in the neighboring Canadian and Mexican markets. The subsequent market rise in many ways parallels the one seen shortly after the 9-11 terrorist attacks in 2001.

This paper's empirical work focuses primarily on the uncertainty effects, demonstrating consistently significant effects of rising US uncertainty on returns across each of the US, Canadian and, to a lesser extent, Mexican markets over the $1 \%$ left tail of the distribution of stock returns. This suggests that the Cuban Missile Crisis did, in fact, heighten the impact of market uncertainty in terms of its contribution to the largest negative stock market returns.

Nevertheless, it is worth pondering why the US stock market especially did not react as negatively, ex ante, as during some other major events in financial history given the heightened uncertainty. We posit that the existential risk associated with the crisis was exaggerated. Unlike genuinely new threats whose impact is entirely unknown, the doomsday scenario associated with nuclear weapons was more than familiar to market participants of the 1960s. What we cannot

\footnotetext{
${ }^{3}$ Other than a positive bump, around the time Kennedy was elected, the fall in the stock market predates the start of the Kennedy administration. The NBER records a recession in 1960-61, as well as two other recessions during the 1950s. See https://www.nber.org/cycles.html.
} 
say is whether or not the uncertainty in question was of the Knightian kind, that is unquantifiable. It appears then that markets assigned a very small risk to the crisis leading to the use of nuclear arsenals despite President Kennedy's pessimism at the height of the Cuban Missile Crisis. Gallup polls around the time of the crisis and soon after (Smith 2003) suggest that, whereas the public was very aware of tensions with Cuba and the financial implications, with a majority (59\%) believing that Cuba was a threat to world peace, the danger of a war was nevertheless seen to be very low (5\% by February 1963).

The rest of the paper is organized as follows. The next section provides a brief historical overview of the Cuban missile crisis. We then document the impact of the crisis on stock markets in the United States, Canada and Mexico. Canada is, of course, a close ally and largest trading partner. Mexico, at the time, was far less economically integrated with the United States than is true today but shares a long border as well as having historical links with Cuba. In section 4 , we present some empirical evidence relying not only on aggregate stock market performance but also, in the U.S. case, on a sample of individual stocks. Given the singular nature of the Cuban missile crisis our approach is empirically eclectic though we rely heavily on the quantile regression approach as this technique seems the most appropriate one under the circumstances. We end with a summary and some conclusions.

\section{Thirteen Days that Shook the World}

Concerns about the destructive power of nuclear weapons were hardly new in 1962. It was less than twenty years since atomic bombs had been dropped on Hiroshima and Nagasaki. Scientists had begun publishing their famous "doomsday clock" as the first series of nuclear tests at Bikini Atoll in July 1946 was followed by an arms race between the United States and the 
Soviet Union. The level of nuclear testing actually peaked in 1961, the year before the Cuban Missile Crisis began. ${ }^{4}$

The Cuban Missile Crisis began with U-2 spy plane photographs showing the installation of Soviet ballistic missiles on the island. The first presentations of this evidence were made in the White House Cabinet Room on the Tuesday morning of October 16, 1962. The US government's decision to respond with a blockade of Cuba was announced to the nation by President Kennedy in his October 22 television address (Kennedy, 1962). Although the blockade was supported at the October 23 meeting of the Organization of American States (OAS), the crisis soon escalated with news of Soviet ships advancing towards the perimeter established as the blockade took effect on October 24 amidst denial of any missile placement from the Soviet government. President Kennedy at this time ordered preparations for an anticipated Soviet closing down of Berlin (Kennedy, 1968, p. 54).

The brinkmanship engaged in at this time is reflected in the fact that, after having initiated the blockade, the actual outcome and potential escalation was no longer under President Kennedy's control. Dixit and Skeath (1999, p. 458) argue that this, in turn, explains why "the risk of war played such an important role in all discussions" [emphasis in original]. Although the encroaching Soviet ships halted or turned back, continued Soviet refusal to recognize the quarantine led to the US development of invasion plans. Indeed, on Friday, October 26, "President Kennedy ordered the State Department to proceed with preparation for a crash program on civil government in Cuba to be established after the invasion and occupation of that country" (Kennedy, 1968, p. 65). Meanwhile, Cuban exile support for a new invasion and calls

\footnotetext{
${ }^{4}$ We relegate to an appendix the "doomsday clock" which reached 2 minutes before midnight in 1953 before rising to 7 minutes before midnight in 1960. It would fall to 12 minutes before midnight in 1963, before remaining closer to the doomsday scenario every year except 1991 and 1995. We also relegate to the appendix a chart on post-World War II nuclear tests.
} 
for military action had already been reported in the Mexico City press (Excelsior, October 23, 1962). It is perhaps for all of these reasons that Arthur Schlesinger, a special assistant of the President, in the foreword of the 1999 edition of Robert Kennedy's (1968) memoir of the event, referred to the Cuban missile crisis as the "...the most dangerous event in human history."

The rising fears of war were allayed only by the conciliatory message from Premier Khruschev that was broadcast on Sunday, October 28, just as "prayers and sermons for peace were being offered in many churches in the United States" (Dixit and Skeath, 1999, p. 443). The rising concerns had been clearly reflected in the stock market, both at home and abroad. This is evidenced, for example, in the following account from the Toronto Globe and Mail on October 24, 1962:

The Cuban crisis sent stock prices skidding on the world's major stock markets yesterday. At Toronto and New York, losses were the sharpest in four months. About the only strength was in issues related to defense, with buying kindles by belief defense contracts might be given to some companies ...

The mixed messages about the impact of the crisis on stock markets were, however, echoed in a New York Times headline, the day after President Kennedy's speech: "Stocks Plunge Early On Crisis, but Rally" (Rutter, 1962). During this period the media did not appear to convey any undue alarm about the emerging crisis notwithstanding the fact that the evolving tensions between the United States and the Soviet Union frequently made the headlines in newspapers such as the New York Times. Indeed, it is only on the day of President Kennedy's speech that the Times published an account of how much of what was happening was being kept from the public (New York Times, 1962). Until that time, reports emphasized the diplomatic route being taken and reported the Soviet claim that the missiles in Cuba were for defensive purposes alone. 
Aside from the United States itself, Canada was likely the most directly implicated in the crisis not only because of the important trading relationship between the two countries but also thanks to the military links under NORAD (North American Aerospace Defense Command). This interdependence was reflected in remarks delivered by Canadian Prime Minister Diefenbaker in the House of Commons soon after President Kennedy's own October 22 address: "[T]he construction of bases for the launching of offensive weapons ... constitutes a threat to most of the cities of North America including our major cities in Canada." ${ }^{5}$ Canadian political and military involvement in the Cuban missile crisis is explained in Haydon's (1993) first-hand account, while Granatstein (1986) provides another historical overview of Canada's role in the crisis. There is also a long history of close financial market linkages, including several stocks cross-listed on Canadian and major US exchanges. ${ }^{6}$ In contrast, Mexico remained publicly more neutral during the Cuban Missile Crisis, even if its sympathies were allegedly biased in favor of Cuba's position. Mexico retained diplomatic relations with Cuba at the time, as did Canadaand the US government was unhappy that Canada's foreign policy did not fully mirror that of the United States.

\section{Documenting the Stock Market Reactions to the Crisis}

Although the Cuban Missile Crisis naturally had worldwide ramifications, the nations most clearly in the eye of the storm remained the United States and its northern and southern neighbors. Daily data on the US S\&P 500 index from 1960-1965 are drawn from Global

\footnotetext{
${ }^{5}$ Quoted in McKercher (2011, pp. 339-340).

${ }^{6}$ Eun and Sabherwal (2003) demonstrate cointegration between prices on the Toronto and New York exchanges and identify feedback to and from the two markets in terms of price changes. Although their study is for a short period in 1998 there is good reason to believe that links of this kind are long-standing (see also Chouimard and D'Souza (2003-2004).
} 
Financial Data. Daily data on the Canadian and Mexican stock market indices had to be handcollected from contemporary newspapers, however. For Canada, data on the TSX Composite index have been merged with earlier data from the TSE 20 index, all drawn from the Toronto Globe and Mail. ${ }^{7}$ Daily data on Mexico's Índice de Precios y Cotizaciones (IPC) are from individual past issues of the Mexico City newspaper Excelsior.

Comparative trends in the three market indices over 1960-1965 are displayed in Figure 1A. This 'long' view of stock market performance for the period 1960 to 1965 covers a sample period selected not only because of data availability but also to highlight the striking rise in stock market indices in all three countries post-Cuban missile crisis. ${ }^{8}$ Subsequent unrelated major events, such as the full onset of the Vietnam war and the fixing of the gold price to the US dollar, would cloud the possibility of any link with the events of October 1962 beyond 1965. Although the Cuban missile crisis did not lead to a collapse in stock prices in the US in the months leading up to the key 'thirteen days' emphasized by Kennedy (1968), the data reveal a reversal from the steady rise that began soon after the election of JFK. Elsewhere in North America, stock market performance in Canada roughly parallels that of the United States whereas Mexican stock price trends are quite different from the other two countries until the end of the Cuban missile crisis in late 1962. Nevertheless, all three markets share a pronounced and sustained rise after the crisis was finally resolved, with Monday, October 29, 1962 marking the first trading after fears of nuclear war had largely banished over the preceding weekend.

Figure 1B presents a different view, focusing on the events in 1962 alone. As shown in the chronology (see Appendix), the principal events surrounding the nuclear tensions that peaked

\footnotetext{
${ }^{7}$ This was facilitated by a period of overlap, over which both indices were provided, prior to the end of the TSE 20 index on November 4, 1963.

${ }^{8}$ The steady rise in stock prices is interrupted by two significant events: the assassination of JFK in November 1963, and the United States' growing involvement in Vietnam.
} 
in October 1962 begin early in that year before being largely dissipated by December. The vertical dashed lines highlight some of the most salient events during this period with the peak in the crisis clearly indicated by the many dashed vertical lines beginning in August and culminating with the October crisis. The differential behavior of stock prices between the US and Canada on the one hand and Mexico on the other is even more striking than in Figure 1A. Stock prices in Mexico display remarkable stability even as stock prices in Canada and the United States enter into a substantial slide that predates the crisis. Indeed, US stock returns fell by more in May and June 1962 than they did on October 23 and by more than on the day of President Kennedy's assassination in November 1963 (not shown; see the appendix). The US market had been declining well before the Cuban Missile Crisis in an extended decline that peaked in late May 1962. Even though the May 28, 1962 paper loss exceeded even that seen on October 28, 1929, Brooks (2014, p. 29) in his first-hand account states that the actual "cause of the crisis remains unfathomable." In any event, panic selling was followed by a partial recovery of the US market before renewed decline coinciding with the onset of the October Cuban Missile Crisis.

The Canadian market reveals a similar pattern to that seen in the US case. The Mexican market, although differing in that it featured consistent gains in the period leading up to the crisis, shared the subsequent downturn around the time of the crisis. Crisis effects seemingly remain elusive across both the Canadian and Mexican markets. There were eleven separate days on which Canadian stock returns fell by larger amounts than what was seen at the height of the Cuban missile crisis, including the day of the Kennedy assassination. Meanwhile, none of the key thirteen crisis days even make the top 20 negative stock returns in Mexico. Indeed, Mexican stock returns actually rose going into the close on October 23, 1962 (result not shown). 
Figure 1C highlights the relative stability of the evolution of stock prices in Canada vs. the United States compared with the gap between the US and Mexican stock prices. Although these differences were already visually suggested in Figure 1B, the dramatic departures during the crisis period are highlighted by the shaded area.

Figure 2 shows stock returns for 38 selected stocks on the NYSE during the thirteen days of the crisis. The following section provides additional details. Some stocks, including such oil and steel stocks as Barber, Bethlehem and Continental, actually rise in response to the President's speech. However, 31 or 38 stocks remain stable or decline on October 23, 1962 relative to the previous day's performance.

Meanwhile, US Treasury data, available since 1962 only and shown in Figure 3, display relative stability during the crisis broken, however, by some sharp one day rises, especially in the $10 \mathrm{Y}-6 \mathrm{M}$ spread. Once the crisis passes, the spreads fall sharply except for the $10 \mathrm{Y} 5 \mathrm{Y}$ spread. Soon after the crisis, spreads begin to fall gradually over the period ending in December 1965 when a sharp fall begins. If financial uncertainty is linked to political uncertainty, then the fall in spreads seems to signal a fall in political uncertainty after the crisis. There is a modest but noticeable rise in all spreads in the weeks leading up to the October Cuba missile crisis.

A qualification is that, well prior to the most troubling public statements about ongoing tensions between the United States and the Soviet Union, news stories about the build-up of Soviet armaments in Cuba had been leaked to the US press. There is no way to determine whether the looming missile crisis explains the downturn in US and Canadian stock prices beginning in the summer of 1962. Nevertheless, as contemporary observer Brooks (2014) had observed, there is no obvious alternative candidate for the visible decline in the two indices. Furthermore, Cuba had been an ongoing source of political and military tensions ever since Fidel 
Castro seized power there in 1959. President Kennedy had himself authorized the ill-fated "Bay of Pigs" invasion of April 1961 less than three months after his inauguration. The October crisis was quite possibly seen as more a deepening of existing strains than a true bolt from the blue. ${ }^{9}$

With the US stock market already in a relatively depressed state by the time the crisis peaked in October $1962,{ }^{10}$ additional downward pressure may itself have been partially countered by the aforementioned buying of defense-related stocks. Another consideration is that, whereas selling stocks short normally offers a way to profit from a negative outcome actually coming to pass, it is not clear that this really works in the case of the Cuban Missile Crisis where the unfavorable result could well mean near-total obliteration. It should certainly have led to elevated uncertainty levels, however, as explored in the empirical work set out below.

We also examined the behavior of commodity prices over the 1960-65 period based on data reported in daily issues of the New York Times. However, owing to a crucial gap between the end of November 1962 and March 1963, we opted not to include the series in the econometric estimation reported in the next section. Figure 4 displays the behavior of some commodity prices around the height of the missile crisis. Also highlighted is the day after President Kennedy's speech to the nation and the world. While the overall index does, for example, suggest a surge the day of the speech and the next it appears mostly driven by a rise in food and related agricultural prices. Thereafter, prices begin a downward trend. ${ }^{11}$ There seems

\footnotetext{
${ }^{9}$ In this regard, Huh and Pyun (2018) identify a significant stock market reaction to North Korea's first nuclear test, but no significant impact of subsequent nuclear-related events.

${ }^{10}$ As Rutter (1962) noted in the New York Times on October $23^{\text {rd }}$ "An already battered stock market..."

${ }^{11} \mathrm{We}$ relegate to the appendix a plot of the entire available sample leaving out a gap for the missing data. Most commodity prices seem to have jumped between the end of November 1962 and March 1963. By 1963, the economy was beginning to recover quickly from the earlier recession. Hence, it is difficult to determine how much of any increase in commodity prices was due to the crisis itself, relief that it had ended peacefully, or the incipient economic recovery.
} 
little visual information in commodity prices not already incorporated in individual stocks chosen for analysis.

\section{Empirical Methodology}

At least three challenges confront researchers investigating the Cuban Missile Crisis period from an econometric perspective. First, the events that took place in October are among the rarest of events one can imagine. Clearly, it is difficult to compare the threat of a nuclear strike with other major economic or political events. Second, although we can date precisely when President Kennedy addressed the nation and told the world about the unfolding crisis, it is clear that the thirteen days in October represents the culmination of events that took place during the calendar year 1962 and, if historians are correct, did not end immediately with the announcement of the withdrawal of missiles at the end of October of that year. Nevertheless, it is convenient for some of the tests presented below, to adopt the October 16-28 period as the period of the crisis. Third, there are only a limited number of time series available at the daily frequency covering this period. Accordingly, we proceed in steps and rely on a variety of econometric techniques and specifications.

We begin by asking whether daily stock returns during the period shown in Figure 1 are subject to structural breaks and whether these can be associated with the crisis. To do so, we estimate the following specification, namely

$$
R_{t}=\alpha+\beta R_{t-1}+\delta K U R T_{t}+\theta D_{t}+\gamma Z_{t}+\varepsilon_{t}
$$

where $\mathrm{R}$ is the daily stock return, calculated as 100 times the log change in the indices plotted in Figure 1, KURT is the 3-day moving kurtosis of stock returns, $\mathrm{Z}$ are controls, D is a dummy variable that captures a structural break, and $\varepsilon$ is the residual term. The timing of the break can 
be imposed based on a chronology of events (see the appendix) or we can let the data speak for itself. We chose the latter strategy as this is the most obvious way to determine whether we can associate the finding of a break with the event that generated it. Moreover, given the potential significance of the break we opt for a dummy that generates an intercept shift, that is, one that results potentially in a permanent change in the remaining coefficients in the equation. One would expect such a reaction to a unique event like the Cuba missile crisis.

Unfortunately, we do not have daily data with which to extract an empirical measure of uncertainty as there are futures indices of expected forward markets prices over the 1960-1965 period. Instead, we use a measure of kurtosis as a representation of uncertainty since this statistic provides a numerical indicator of the thickness of the tails of a distribution and, hence, the likelihood of rare events. In finance this metric is often used to proxy uncertainty (e.g., Rogers and Siklos 2003).

The literature dealing with economic uncertainty has mushroomed in recent years but there is, as yet, nothing approaching a consensus of its proximate determinants. Moreover, uncertainty comes in several forms and, although political components are not always considered, this is changing (see, for example, Kozeniauskas, et. al., 2016, Castelnuovo, 2018, and Dai and Zhang, 2019, for recent surveys). Interestingly, in empirical exercises, uncertainty is often associated with disagreement among individuals over, for example, the economic outlook (Orlik and Veldkamp, 2015; Koslowski et. al., 2018; and Koslowski et. al., 2020). One take-away from this literature is that rare events can have persistent macroeconomic effects. Nevertheless, for the reasons outlined above, it is difficult to conceive the of Cuban missile crisis as a true 'black swan' event. 
Other controls are captured by $\mathrm{Z}_{\mathrm{t}}$ and these can include other dummies for other events unrelated to the crisis and other determinants of stock returns. For some of the test reported below we consider other variables thought to potentially impact stock returns. One such potential factor that frequently appears in the literature concerns term spreads ${ }^{12}$ and one such term spread is shown in Figure $3 .^{13}$ The Bai-Perron $(1998,2003 \mathrm{a}, 2003 \mathrm{~b})$ test is then used to endogenously obtain estimates of the timing and number of structural breaks. A drawback of this testing procedure is that breaks are assumed to occur on a particular day and there is no test for breaks with durations that exceed one day in our case. The alternative is to pre-specify a break dummy with a specified duration. However, this would defeat the idea of letting the data speak for themselves.

Therefore, in a second step, we estimate a version of equation (1) but now only for a portion of the distribution of stock returns. Although we know that events such as the Cuban missile crisis are rare, it is unclear over which portion of the distribution of returns we should limit our estimates. We considered a few alternatives, but the results discussed below are estimated for the $1 \%$ and $10 \%$ left tail of the distribution of returns. ${ }^{14}$ The left tail is considered since an event such as the missile crisis is expected to produce a sharp reduction in returns (i.e., negative returns). The quantile regression method (Koenker 2005) is used. ${ }^{15}$ This results in a specification of the form:

\footnotetext{
${ }^{12}$ It is beyond the scope of this paper to survey the links between stock returns, economic activity and term spreads. However, see, for example, Bauer and Mertens (2018) who provide a brief summary of the literature and conclude that "[T] he term spread...is a strikingly accurate predictor of future economic activity."

${ }^{13}$ Comparable spreads for Canada and Mexico are not available. We used US spreads in the regressions for Canadian and Mexican stock returns but our conclusions are unaffected.

${ }^{14}$ Clearly, the smaller the portion of the distribution examined the 'rarer' the event that is considered.

15 There are other methodologies that one could use (e.g., extreme value theory). There is a connection between the two methodologies and one issue is whether the sampling theory for quantile regressions applies in the present case. In this connection see, for example, Chernozhukov (2005). Not everyone is convinced that special considerations apply to the empirical analysis of stock market crashes like the Great Depression or othe such events. See Gabaix et. al. (2006).
} 


$$
Q_{R, t}(\tau \mid K U R T)=\alpha(\tau)+\beta R_{t-1}(\tau)+\delta K U R T(\tau)_{t}+\theta D(\tau)_{t}+\gamma Z(\tau)_{t}+F_{\varepsilon}^{-1}(\tau)
$$

where all the variables have been previously defined and Q(-) refers to the quantile function, $\tau$ the quantile over which the function is estimated, and $\mathrm{F}$ represents the common distribution function of the errors.

Since uncertainty is associated with volatility, and by way of comparison, we also estimate, for the US case only due to data limitations, a component GARCH $(1,1)$ model. GARCH models are, of course, ubiquitous in finance and for the modelling of stock returns. To capture the possibility that volatility persistence has both short-run and long-run components, Dinge and Granger (1996), and Engle and Lee (1999) propose an extension of the GARCHH $(1,1)$ model, called a component GARCH model, to capture these effects. The resulting model, omitting variables other than lagged returns, is written as follows:

$$
\begin{gathered}
r_{t}=\alpha+\beta r_{t-1}+\sqrt{h_{t} z_{t}} \\
h_{t}=q_{t}+\alpha\left(\epsilon_{t-1}^{2}-q_{t-1}\right)+\beta\left(h_{t-1}-q_{t-1}\right) \\
q_{t}=\omega+\rho\left(\epsilon_{t-1}^{2}-h_{t-1}\right)+\delta\left(q_{t-1}-\omega\right)
\end{gathered}
$$

where $\mathrm{h}(\mathrm{t})$ models the short-run volatility response while $\mathrm{q}(\mathrm{t})$ capture the long-run component. Long-run persistence is captured by the sum $\delta+\rho$ while the usual GARCH terms are given by $\alpha+\beta$.

Finally, with CRSP providing daily stock return data since 1925 , we also estimate a version of equations (1) and (2) for 38 individual stocks. These were selected not only because they are likely to be impacted by events such as the Cuban Missile Crisis but also due to many of these stocks being highlighted in the immediate aftermath of President Kennedy's address to the nation (details in Appendix). KURT is now replaced by an indicator of disagreement between aggregate stock returns and individual stocks returns. More precisely, we remove the 
macroeconomic component of individual stock returns by subtracting the residuals obtained from a regression of aggregate stock returns (i.e., the daily returns on S\&P 500) on the change in 10year-5year term spread. The resulting series then squared is meant to proxy disagreement between individual and aggregate stock returns. Since we have at our disposal volume data, we follow many others in the literature and add trading volume as an additional determinant. Finally, a dummy variable set to one to identify the Cuban Missile Crisis, is added and is the focus of interest. The returns used are obtained from CRSP and they exclude dividends.

\section{Estimation Results}

There are two main components to the empirical work derived from the section above. The first set of results asks whether there are any statistical breaks in stock market returns in the three countries and when. We repeat the same exercise for the individual stock returns we have collected. Uncertainty is seen as influencing returns, conditional on lagged returns and the change in interest rate spreads, and is itself proxied by the 3-day moving kurtosis of stock returns. ${ }^{16}$ The second set asks what the link is between uncertainty and returns, conditioned the same way as in the breaks test, at the very lowest tails (i.e., highest negative returns) of the distribution of returns.

Table 1 summarizes the estimate breaks in returns at both the aggregate and at the level of individual stocks. The former set are discussed in greater detail below. Turning to the individual stocks the majority ( 23 of 38 stocks) do not experience a break over the 1962-1965 period. And, with one exception, breaks in stocks only take place during 1962. Moreover, all the breaks take place several months before the peak in crisis. It is, however, worth noting that

\footnotetext{
${ }^{16}$ The regressions shown only allow for US uncertainty to impact returns in the 3 countries. Substituting own market uncertainty in the Canadian and Mexican regressions does not change the conclusions.
} 
tensions with Cuba during 1962 competed with the Kennedy administration's battle with the steel industry - which was alleged to have been engaged in price fixing, leading to anti-trust suits in the late Spring of 1962.

Table 2 show the results for the three markets considered over the full 1962-1965 sample period as well as for data for 1962 alone which, as previously explained, captures the period when tensions between Cuba and the US first emerged until the end of the year when the crisis ostensibly ended. Although no breaks are found for Mexico, significant breaks are dated June 14, 1962 for the United States; and July 24, 1962, and November 14, 1962 for Canada. There are no breaks outside 1962. Prior to the first break, uncertainty reduces stock returns in both the US and Mexico by comparable amounts. A post-break rise in uncertainty is positively related with stock returns in both the US and Canada and, again, the coefficients are similar.

If we focus the testing on 1962 data alone, there is a significant US break on October 23, 1962, which is the day after Kennedy's television address about the Cuban missile crisis. Another US break occurs on November 14, 1962. For Canada, the results are largely unchanged compared with the ones shown earlier, though one less break is found, while for Mexico a significant break is seen for December 6, 1962. In general, uncertainty is seen as raising US returns, but only after the peak of the crisis. For Canada the link between uncertainty and the crisis disappears and there is similarly no link found in Mexican data. The spillovers from US uncertainty to Canada and Mexico also largely disappear although, post-break, there is a rise in Canadian returns in response to a higher spread. Of course, a higher spread is indicative of improved future macroeconomic outcomes.

Table 3 also provides estimates from a $\operatorname{CGARCH}(1,1)$ model. Here the emphasis shifts to changes in conditional volatility. We observed that the Cuban Missile Crisis dummy (CMC) 
contributes to reduce the S\&P 500 stock returns. The volatility equations indicate not only a positive impact in short-run conditional volatility (i.e., $\alpha+\beta$ ) but the presence of considerable long-run volatility persistence (i.e., $\rho+\delta) .{ }^{17}$ Clearly, the crisis left scars on stock returns though not to the extent that accords with some priors about the impact of such events. Indeed, as shown in Figure 5 which displays the variances from the CGARCH model, three events stand out over the 1962-1965 period. They are: the Kennedy administration's battle with the steel industry in May 1962, the Cuban Missile Crisis in late October of the same year and, finally, the fallout from President Kennedy’s assassination in November 1963.

A difficulty with the results so far is that breaks are one-time events. Whereas the worst of the Cuban missile crisis occurred on a particular day, the actual crisis evolved over a period of days, if not months. Accordingly, Table 3 shows the same regression as in Table 2 but now focusing solely on the behavior of returns and uncertainty in the left tail of the distribution. In particular, we zero in on the $1 \%$ and $10 \%$ left tails of the distribution that contains the very largest negative returns. In this context, US uncertainty is now seen to exert a negative impact on returns in all three markets and the size of the negative response to a rise in uncertainty is comparable across the US, Canadian, and Mexican markets. Interestingly, the impact of greater uncertainty on returns is much higher at the very lowest left tail of the distribution. Therefore, uncertainty not only reduces returns when they are relatively large and negative but the largest negative returns incur a much bigger drop than others. By contrast, when we examine the mean or median of the distribution (results not shown), we find that uncertainty is either unrelated to stock returns or else that the coefficients, when statistically significant (US case only), are

\footnotetext{
${ }^{17}$ Estimates for a conventional GARCH( 1,1$)$ model yield similar results for the mean and variance equations. The latter display relatively more volatility persistence because short-run and long-run persistence are conflated. We also estimate GARCH models for individual stock returns but these, in general, fare poorly (results not shown).
} 
considerably smaller. Hence, the evidence suggests that the Cuban Missile Crisis did, in fact, heighten the impact of market uncertainty in terms of its contribution to the largest negative stock market returns.

Table 4 presents the final set of results. To conserve space (detailed results are available on request) we only show three sets of results. They are: the coefficient and statistical significance of the dummy variable for the thirteen days of the Cuban Missile Crisis (i.e., October $16-28,1962$ ), a statistical test to determine whether estimates at the $1 \%$ quantile differ

from the ones at the $10 \%$ quantile, and a test whether quantile estimates at the left tail differ from ones at the upper right tails of the distribution of returns (i.e., $90 \%$ and $99 \%$ quantile). The last test provides some indication of whether there is asymmetry in the behavior of returns in both tails of the distribution.

The results suggest that returns depressed returns, but the effect is generally significant at the $1 \%$ left tail of the distribution. Indeed, at the $10 \%$ quantile there are several examples of the crisis raising returns. It is also overwhelmingly the case that estimates at the $1 \%$ quantile differ from the estimates at the $10 \%$ quantile. Finally, there is also considerable support for the view that stock returns in the left tail of the distribution differ from ones that would be obtained for stock that experienced the highest returns.

\section{Conclusions}

Although the resolution of the Cuban Missile Crisis was followed by a sustained recovery in the US, Canadian and Mexican stock markets, the initial stock market impact of the crisis itself seems rather modest even in comparison with market declines seen earlier in the year. Empirical analysis of 1962 US stock market data does reveal a significant break on October 23, 
1962, which is the day after President Kennedy's television address about the Cuban missile crisis. The most convincing evidence of crisis effects emerges when we focus on the $1 \%$ left tail of the distribution, however. In terms of this region of largest negative market returns, US uncertainty is now seen to have a significant negative impact on returns across each of the US, Canadian and Mexican markets. Moreover, the size of the negative response to the rise in uncertainty is very similar in all three cases notwithstanding the fact the pre-crisis Mexican stock market trajectory had been very different from that seen in the United States and Canada. 


\section{References}

Bai, Jushan and Pierre Perron (1998), "Estimating and Testing Linear Models with Multiple Structural Changes," Econometrica 66 (January): 47-78.

Bai, Jushan and Pierre Perron (2003a). "Computation and Analysis of Multiple Structural

Change Models," Journal of Applied Econometrics 18 (January-February): 1-22.

Bai, Jushan and Pierre Perron (2003b). "Critical Values for Multiple Structural Change Tests," Econometrics Journal 6 (1): 72-78.

Bauer, M., and T. Mertens (2018), "Economic Forecasts with the Yield Curve," Federal Reserve Bank of San Francisco Economic Letter 2018-07, March 5.

Bloom, Nicholas (2009), “The Impact of Uncertainty Shocks,” Econometrica 77 (May): 623685.

Brooks, John (2014), Business Adventures: Twelve Classic Tales from the World of Wall Street (New York: Open Road Integrated Media).

Burdekin, Richard C. K., Eric Hughson and Jinlin Gu (2018), “A First Look at Brexit and Global Equity Markets," Applied Economics Letters, Vol. 25 (2): 136-140.

Castelnuovo, Efrem (2019), "Domestic and Global Uncertainty: A Survey and Some New Results,” Melbourne Institute for Applied Economics and Social Research, Working Paper 13/19.

Chernozhukov, Victor (2005), “Extremal Quantile Regression,” Annals of Statistics 33 (2): 806839.

Chouinard, Éric and Chris D’Souza (2003-2004), “The Rationale for Cross-Border Listings,” Bank of Canada Review (Winter): 23-30. 
Dai, Lili and Bohui Zhang (2019), "Policy Uncertainty and Finance: A Survey," Asia Pacific Journal of Financial Studies 48 (June): 307-33.

Ding, Zhuanxin and Clive W. J. Granger (1996), "Modelling Volatility Persistence of Speculative Returns: A New Approach," Journal of Econometrics 73 (July): 185-215.

Dixit, Avinash and Susan Skeath (1999), Games of Strategy (New York: W.W. Norton).

Engle, Robert F. and Gary G. J. Lee (1999), “A Long-Run and Short-Run Component Model of Stock Return Volatility," in Robert F. Engle and Halbert White (Eds.), Cointegration, Causality, and Forecasting: A Festschrift in Honour of Clive Granger (Oxford: Oxford University Press), pp. 475-497.

Eun, Cheol S. and Sanjiv Sabherwal (2003), “Cross-Border Listings and Price Discovery:

Evidence from U.S.-Listed Canadian Stocks," Journal of Finance 58 (April): 549-575. Excelsior (1962), "Propugnan la Invasíon de Cuba los Desterrados" [The exiles support the invasion of Cuba], October 23.

Gabaix, Xavier, Parameswaran Gopikrishnan, Vasiliki Plerou, and H. Eugene Stanley (2006), "Institutional Investors and Stock Market Volatility," Quarterly Journal of Economics 121 (May): 461-504.

Granatstein, J. L. (1986), Canada 1957-1967: The Years of Uncertainty and Innovation (Toronto: McLelland and Stewart).

Haydon, P. (1993), The 1962 Cuban Missile Crisis: Canadian Involvement Reconsidered (Toronto: Canadian Institute of Strategic Studies).

Huh, In and Ju Hyun Pyun (2018), "Does Nuclear Uncertainty Threaten Financial Markets? The Attention Paid to North Korean Nuclear Threats and Its Impact on South Korea's Financial Markets," Asian Economic Journal, Vol 32 (1): 55-82. 
Kennedy, John Fitzgerald (1962), Address by President Kennedy, October 22.

Kennedy, Robert F. (1968), Thirteen Days: A Memoir of the Cuban Missile Crisis (New York: W.W. Norton, 1999 reprint).

Koenker, Roger (2005), Quantile Regression (New York: Cambridge University Press).

Koslowski, Julian, Laura Veldkamp and Venky Venkateswaran (2018), “The Tail That Keeps the Riskless Rate Low,” NBER Working Paper 24362, February.

Koslowski, Julian, Laura Veldkamp and Venky Venkateswaran (2020), “The Tail That Wags the Economy: Beliefs and Persistent Stagnation," Journal of Political Economy (forthcoming).

Kozeniauskas Nicholas, Anna Orlik, and Laura Veldkamp (2016), “The Common Origins of Uncertainty Shocks," NBER Working Paper 22384, July.

May, Ernest R. and Philip D. Zelikow, eds. (1997), The Kennedy Tapes: Inside the White House during the Cuban Missile Crisis (Cambridge, MA: Belknap Press of Harvard University Press).

McCrum, Dan (2018), "Stocks and the Cuban Missile Crisis," Financial Times, April 11 [https://ftalphaville.ft.com/2018/04/11/1523451199000/Stocks-and-the-Cuban-missilecrisis/].

McKercher, Asa (2011), “A 'Half-hearted Response’?: Canada and the Cuban Missile Crisis, 1962," International History Review 33 (June): 335-352.

New York Times (1962), “Capital's Discussions in Crisis Kept Tight Secret for a Week,” October 22.

Orlik, Anna and Laura Veldkamp (2015), "Understanding Uncertainty Shocks and the Role of Black Swans,” NBER Working Paper 20445, October. 
Rogers, J. M. and P. L. Siklos (2003), "Foreign Exchange Market Intervention in Two Small Open Economies: The Canadian and Australian Experience," Journal of International Money and Finance 22 (June): 393-416.

Rutter, Richard. (1962), “Stocks Plunge Early On Crisis, but Rally,” New York Times, October 23.

Smith, Tom W. (2003), "The Polls_-Trends: The Cuban Missile Crisis and U.S. Public Opinion,” Public Opinion Quarterly 67 (Summer): 265-293. 
Table 1: Dating Statistical Breaks in the US Stock Market Data, 1962-1965

\begin{tabular}{|c|c|c|c|c|c|}
\hline Data & Sample & US & Canada & Mexico & \\
\hline Stock Index & $\begin{array}{l}1962 / 04 / 01 \\
1965 / 12 / 31\end{array}$ & $6 / 14 / 1962$ & $\begin{array}{c}7 / 24 / 1962 \\
11 / 14 / 1962\end{array}$ & None & \\
\hline Stock Index & $\begin{array}{l}1962 / 04 / 01 \\
1962 / 12 / 31\end{array}$ & $\begin{array}{l}10 / 23 / 1962 \\
11 / 14 / 1962\end{array}$ & $7 / 24 / 1962$ & $12 / 6 / 1962$ & \\
\hline Company & $\begin{array}{c}S: 1962 / 04 / 01 \\
1965 / 12 / 31\end{array}$ & Company & $\begin{array}{c}S: 1962 / 04 / 01 \\
1965 / 12 / 31\end{array}$ & Company & $\begin{array}{c}S: 1962 / 04 / 01 \\
1965 / 12 / 31\end{array}$ \\
\hline $\begin{array}{l}\text { Amer. } \\
\text { Motors }\end{array}$ & & Ford & $1962 / 7 / 25$ & Royal Dutch & $1965 / 2 / 10$ \\
\hline Atlantic & & $\mathrm{GE}$ & & Ryerson & $1962 / 6 / 27$ \\
\hline Barber & & Gen. Amer. & $1962 / 6 / 11$ & Santa Fe & \\
\hline Bethlehem & $1962 / 6 / 11$ & GM & & Seabord & \\
\hline Boeing & $1962 / 6 / 5$ & Granite & & Spartans & \\
\hline Chevron & & Kodak & & Union Carbide & \\
\hline Chrysler & & Lockheed & & Unisys & $1962 / 8 / 30$ \\
\hline Continental & & $\begin{array}{l}\text { Martin } \\
\text { Marietta }\end{array}$ & $1962 / 6 / 14$ & Union Pacific & $1962 / 12 / 5$ \\
\hline \multirow[t]{2}{*}{$\begin{array}{l}\text { Curtis- } \\
\text { Wright }\end{array}$} & & $\begin{array}{l}\text { North Amer. } \\
\text { Sugar }\end{array}$ & $\begin{array}{c}1962 / 10 / 29 \\
1963 / 5 / 27\end{array}$ & \multirow[t]{2}{*}{ US Steel } & \\
\hline & & NCR & $1962 / 7 / 31$ & & \\
\hline Douglas & & Pharmacia & $1962 / 5 / 14$ & Westinghouse & \\
\hline ESB & & Pitney & $1962 / 6 / 14$ & Xerox & \\
\hline $\begin{array}{l}\text { Exxon- } \\
\text { Mobil }\end{array}$ & $1962 / 3 / 4$ & Polaroid & $1962 / 6 / 14$ & Zenith & \\
\hline
\end{tabular}

Note: See Table 2 for test details. Dates shown are (yyyy/m/d). Breaks are for the level of daily returns (ex dividends). 
Table 2 Uncertainty, Volatility, and Stock Returns: 1962-1965

\begin{tabular}{|c|c|c|c|}
\hline Variable & United States & Canada & Mexico \\
\hline Date of Break & $6 / 14 / 1962$ & $\begin{array}{c}7 / 24 / 1962 \\
11 / 14 / 1962\end{array}$ & NONE \\
\hline$r_{t-1}$ & $\begin{array}{c}0.60(0.09) * \\
0.13(0.12)\end{array}$ & $\begin{array}{c}0.36(0.09)^{*} \\
-0.47(0.10)^{*} \\
0.15(0.05)^{*}\end{array}$ & $0.01(0.06)$ \\
\hline$U_{S U n c_{t}}$ & $\begin{array}{c}-0.08(0.05) @ \\
0.06(0.02)^{*}\end{array}$ & $\begin{array}{c}-0.07(0.05) \\
0.04(0.06) \\
0.07(0.02)^{*}\end{array}$ & $-0.05(0.02)^{*}$ \\
\hline$\Delta S_{t}$ & $\begin{array}{c}11.46(4.59)^{*} \\
-3.76(5.43)\end{array}$ & $\begin{array}{c}-14.53(5.38)^{*} \\
20.46(9.40)+ \\
3.45(3.76)\end{array}$ & $0.38(2.30)$ \\
\hline $\mathrm{R}^{2}$ & 0.13 & 0.11 & 0.0002 \\
\hline $\mathrm{T}$ & 559 & 556 & 538 \\
\hline Sample & $1 / 4 / 1962-12 / 31 / 1965$ & $1 / 4 / 1962-12 / 31 / 1965$ & $1 / 4 / 1962-12 / 31 / 1965$ \\
\hline Date of Break & $\begin{array}{l}10 / 23 / 1962 \\
11 / 14 / 1962\end{array}$ & $7 / 24 / 1962$ & $12 / 06 / 1962$ \\
\hline$r_{t-1}$ & $\begin{array}{c}0.42(0.10)^{*} \\
-0.64(0.08)^{*} \\
-0.16(0.17)\end{array}$ & $\begin{array}{c}0.36(0.12)^{*} \\
-0.42(0.13)^{*}\end{array}$ & $\begin{array}{c}0.04(0.09) \\
-1.19(0.26)^{*}\end{array}$ \\
\hline
\end{tabular}




\begin{tabular}{|c|c|c|c|}
\hline USUnc $_{t}$ & $-0.02(0.05)$ & $-0.07(0.05)$ & $-0.02(0.03)$ \\
& $0.67(0.10)^{*}$ & $0.09(0.05)$ & $-0.40(0.34)$ \\
& $0.19(0.06)^{*}$ & & \\
\hline$\Delta S_{t}$ & $-2.28(11.17)$ & $-14.54(0.13)$ & $0.96(2.75)$ \\
& $-39.85(50.38)$ & $16.72(4.69)^{*}$ & $-27.38(23.56)$ \\
& $6.16(9.04)$ & & \\
\hline $\mathrm{R}^{2}$ & 0.27 & 0.26 & 0.16 \\
\hline $\mathrm{T}$ & 138 & 135 & 133 \\
\hline Sample & $1 / 4 / 1962-12 / 31 / 1962$ & $1 / 4 / 1962-12 / 31 / 1962$ & $1 / 4 / 1962-12 / 31 / 1962$ \\
\hline
\end{tabular}

Notes: $r_{t}$ is the daily return (ex dividends), USUnc is the 3 day moving kurtosis, $\Delta S_{t}$ is the daily change in the 10Y-5Y interest rate spread. Structural breaks estimated using the Bai-Perron test with a trimming factor of $5 \%$, breaks are statistically significant at the $10 \%$ level; Newey-West standard errors are reported; and the null of $\mathrm{K}+1$ versus $\mathrm{K}$ structural breaks is specified with a maximum of 5 breaks. The only exception is for Canada for the 1962 sample where 1 break is imposed as the alternative led to 3 breaks with fewer that 15 observation in each regime. * means significant at the 1\%(+5\%,@10\%) level. T is the number of observations. 
Table 3: Tail Behavior or Returns

\begin{tabular}{|c|c|c|c|c|c|c|c|}
\hline \multirow[t]{2}{*}{ Variable } & \multicolumn{3}{|l|}{ United States } & \multicolumn{2}{|l|}{ Canada } & \multicolumn{2}{|l|}{ Mexico } \\
\hline & $\tau=.01$ & $\tau=.1$ & CGARCH $(1,1)$ & $\tau=.01$ & $\tau=.1$ & $\tau=.01$ & $\tau=.1$ \\
\hline$r_{t-1}$ & $0.33(0.67)$ & $0.44(004)^{*}$ & $0.14(0.04)^{*}$ & $-0.17(0.33)$ & $0.20(0.04)^{*}$ & $-0.01(0.14)$ & $-0.01(0.07)$ \\
\hline$U S U n c_{t}$ & -1.08(0.60)@ & $-0.40(0.03)^{*}$ & NA & $-1.28(0.41)^{*}$ & $-0.28(0.03)^{*}$ & $-1.07(0.12)^{*}$ & $-0.38(0.02)^{*}$ \\
\hline$\Delta S_{t}$ & $1.57(238.34)$ & $9.12(4.46)+$ & $1.32(1.17)$ & $10.46(42.29)$ & $0.39(5.27)$ & $-9.19(12 / 94)$ & $1.88(3.25)$ \\
\hline Break Dummy & & & $0.06(0.01)^{*}$ & & & & \\
\hline $\mathrm{CMC}$ & & & $-0.38(0.18)+$ & & & & \\
\hline$\omega$ & & & 0.34(0.20)@ & & & & \\
\hline$\rho$ & & & $0.97(0.01)^{*}$ & & & & \\
\hline$\delta$ & & & $-0.14(0.05) *$ & & & & \\
\hline$\alpha$ & & & $0.22(0.06)^{*}$ & & & & \\
\hline$\beta$ & & & $0.43(0.15)^{*}$ & & & & \\
\hline $\mathrm{PR}^{2}$ & 0.14 & 0.14 & 0.01 & 0.04 & 0.03 & 0.02 & 0.001 \\
\hline $\mathrm{T}$ & 559 & 559 & 933 & 556 & 556 & 538 & 538 \\
\hline
\end{tabular}

Note: Notes: Quantile regression at the 0.01 and .1 quantiles (large negative return) with bootstrap (mcm method; 1000 replciations) standard errors; Epanechnikov kernel; and Hall-Sheather bandwidth method. Also, see notes to Table 2. CGARCH(1,1) estimated via Maximum likelihood. Break dummies are the ones estimated in Table 2; CMC is a dummy equal to 1 during the Cuba Missile Crisis (Oct. 16-28, 1962). 
Table 4: Tail Behavior of Individual Stock Returns: Selected Results

\begin{tabular}{|c|c|c|c|c|c|c|c|c|c|c|c|}
\hline Stock & $\tau$ & $\theta_{4}$ & SET & $\mathrm{SQT}$ & $\mathrm{PR}^{2}$ & Stock & $\tau$ & $\theta_{4}$ & SET & $\mathrm{SQT}$ & $\mathrm{PR}^{2}$ \\
\hline Amer Motors & $\begin{array}{l}.01 \\
.01 \\
.10 \\
.10 \\
\end{array}$ & $\begin{array}{c}-.01 \\
-.02 \\
.01 \\
-0.03 @ \\
\end{array}$ & $\begin{array}{l}.70 \\
.00 \\
.71 \\
.00 \\
\end{array}$ & $\begin{array}{l}.00 \\
.00 \\
.00 \\
.00 \\
\end{array}$ & $\begin{array}{l}.40 \\
.05 \\
.08 \\
.02 \\
\end{array}$ & Lockheed & $\begin{array}{l}.01 \\
.01 \\
.10 \\
.10 \\
\end{array}$ & $\begin{array}{c}.01 \\
-.01 \\
-.03 @ \\
-.01 @\end{array}$ & $\begin{array}{l}.04 \\
.16 \\
.02 \\
.16 \\
\end{array}$ & $\begin{array}{l}.77 \\
.00 \\
.75 \\
.00 \\
\end{array}$ & $\begin{array}{l}.08 \\
.02 \\
.01 \\
.01 \\
\end{array}$ \\
\hline Atlantic & $\begin{array}{l}.01 \\
.01 \\
.10 \\
.10 \\
\end{array}$ & $\begin{array}{c}.02 @ \\
-.01 \\
.06 * \\
.01 \\
\end{array}$ & $\begin{array}{l}.00 \\
.00 \\
.00 \\
.00 \\
\end{array}$ & $\begin{array}{l}.01 \\
.02 \\
.01 \\
.04 \\
\end{array}$ & $\begin{array}{l}.03 \\
.02 \\
.02 \\
.001 \\
\end{array}$ & Martin & $\begin{array}{l}.01 \\
.01 \\
.10 \\
.10 \\
\end{array}$ & $\begin{array}{c}-.005 \\
-.02 \\
.01 \\
-.02 \\
\end{array}$ & $\begin{array}{l}.00 \\
.00 \\
.00 \\
.00 \\
\end{array}$ & $\begin{array}{l}.00 \\
.01 \\
.00 \\
.00 \\
\end{array}$ & $\begin{array}{l}.11 \\
.01 \\
.01 \\
.003 \\
\end{array}$ \\
\hline Barber & $\begin{array}{l}.01 \\
.01 \\
.10 \\
.10 \\
\end{array}$ & $\begin{array}{c}.002 \\
-.01+ \\
.04 * \\
-.002 \\
\end{array}$ & $\begin{array}{c}.002 \\
-.01+ \\
.04 * \\
-.002 \\
\end{array}$ & $\begin{array}{l}.00 \\
.00 \\
.00 \\
.00 \\
\end{array}$ & $\begin{array}{l}.17 \\
.04 \\
.05 \\
.01 \\
\end{array}$ & NA Sugar & $\begin{array}{l}.01 \\
.01 \\
.10 \\
.10 \\
\end{array}$ & $\begin{array}{c}.02 \\
-.09+ \\
.02 \\
-.08 @ \\
\end{array}$ & $\begin{array}{l}.02 \\
.00 \\
.02 \\
.00 \\
\end{array}$ & $\begin{array}{l}.09 \\
.01 \\
.08 \\
.00 \\
\end{array}$ & $\begin{array}{l}.31 \\
.06 \\
.10 \\
.03 \\
\end{array}$ \\
\hline Bethlehem & $\begin{array}{l}.01 \\
.01 \\
.10 \\
.10 \\
\end{array}$ & $\begin{array}{c}-.04 \\
-.07+ \\
-.03 \\
-.06+\end{array}$ & $\begin{array}{c}-.04 \\
-.07+ \\
-.03 \\
-.06+\end{array}$ & $\begin{array}{l}.19 \\
.00 \\
.15 \\
.00\end{array}$ & $\begin{array}{c}.226 \\
.14 \\
.03 \\
.06 \\
\end{array}$ & NCR & $\begin{array}{l}.01 \\
.01 \\
.10 \\
.10 \\
\end{array}$ & $\begin{array}{c}-.04 \\
-.04 * \\
-.01 \\
-.03 *\end{array}$ & $\begin{array}{l}.64 \\
.00 \\
.65 \\
.00 \\
\end{array}$ & $\begin{array}{l}.24 \\
.00 \\
.23 \\
.00 \\
\end{array}$ & $\begin{array}{l}.11 \\
.01 \\
.04 \\
.01 \\
\end{array}$ \\
\hline Boeing & $\begin{array}{l}.01 \\
.01 \\
.10 \\
.10 \\
\end{array}$ & $\begin{array}{c}.01+ \\
-.01 @ \\
-.01 \\
-.01 * \\
\end{array}$ & $\begin{array}{l}.00 \\
.57 \\
.00 \\
.53 \\
\end{array}$ & $\begin{array}{l}.40 \\
.00 \\
.38 \\
.00 \\
\end{array}$ & $\begin{array}{l}.07 \\
.02 \\
.04 \\
.01 \\
\end{array}$ & Pharmacia & $\begin{array}{l}.01 \\
.01 \\
.10 \\
.10 \\
\end{array}$ & $\begin{array}{c}-.01 \\
-.02+ \\
.01 \\
-.02 @ \\
\end{array}$ & $\begin{array}{l}.53 \\
.00 \\
.48 \\
.00 \\
\end{array}$ & $\begin{array}{l}.00 \\
.03 \\
.01 \\
.03 \\
\end{array}$ & $\begin{array}{l}.09 \\
.05 \\
.02 \\
.02 \\
\end{array}$ \\
\hline Chevron & $\begin{array}{l}.01 \\
.01 \\
.10 \\
.10 \\
\end{array}$ & $\begin{array}{l}-.001 \\
-.02 * \\
-.04+ \\
-.01+ \\
\end{array}$ & $\begin{array}{l}.00 \\
.20 \\
.01 \\
.24 \\
\end{array}$ & $\begin{array}{l}.15 \\
.00 \\
.11 \\
.00 \\
\end{array}$ & $\begin{array}{l}.25 \\
.04 \\
.05 \\
.01 \\
\end{array}$ & Pitney & $\begin{array}{l}.01 \\
.01 \\
.10 \\
.10 \\
\end{array}$ & $\begin{array}{c}.001 \\
-.04+ \\
-.003 \\
-.004 \\
\end{array}$ & $\begin{array}{l}.09 \\
.00 \\
.07 \\
.00 \\
\end{array}$ & $\begin{array}{l}.65 \\
.00 \\
.67 \\
.00 \\
\end{array}$ & $\begin{array}{l}.16 \\
.15 \\
.01 \\
.02 \\
\end{array}$ \\
\hline Chrysler & $\begin{array}{l}.01 \\
.01 \\
.10 \\
.10 \\
\end{array}$ & $\begin{array}{c}-.003 \\
-.02 * \\
-.01 \\
-.02+\end{array}$ & $\begin{array}{l}.05 \\
.00 \\
.05 \\
.00 \\
\end{array}$ & $\begin{array}{l}.15 \\
.00 \\
.22 \\
.00\end{array}$ & $\begin{array}{c}.08 \\
.03 \\
.002 \\
.01 \\
\end{array}$ & Polaroid & $\begin{array}{l}.01 \\
.01 \\
.10 \\
.10 \\
\end{array}$ & $\begin{array}{c}.02 \\
.002 \\
-.003 \\
-.03 * \\
\end{array}$ & $\begin{array}{l}.13 \\
.00 \\
.12 \\
.00\end{array}$ & $\begin{array}{l}.20 \\
.00 \\
.17 \\
.00 \\
\end{array}$ & $\begin{array}{l}.34 \\
.22 \\
.13 \\
.06\end{array}$ \\
\hline Continental & $\begin{array}{l}.01 \\
.01\end{array}$ & $\begin{array}{l}.02+ \\
-.01\end{array}$ & $\begin{array}{l}.00 \\
.00\end{array}$ & $\begin{array}{l}.06 \\
.00\end{array}$ & $\begin{array}{l}.17 \\
.03\end{array}$ & Royal Dutch & $\begin{array}{l}.01 \\
.01\end{array}$ & $\begin{array}{c}-.02 \\
-.04+\end{array}$ & $\begin{array}{l}- \\
. .28\end{array}$ & $\begin{array}{l}.59 \\
.01\end{array}$ & $\begin{array}{l}.28 \\
.11\end{array}$ \\
\hline
\end{tabular}




\begin{tabular}{|c|c|c|c|c|c|c|c|c|c|c|c|}
\hline & $\begin{array}{l}.10 \\
.10\end{array}$ & $\begin{array}{l}.04^{*} \\
.01\end{array}$ & $\begin{array}{l}.00 \\
.00\end{array}$ & $\begin{array}{l}.08 \\
.00\end{array}$ & $\begin{array}{l}.04 \\
.01\end{array}$ & & $\begin{array}{l}.10 \\
.10\end{array}$ & $\begin{array}{c}-.03 \\
-.05+\end{array}$ & $\begin{array}{l}.00 \\
.26 \\
.00 \\
\end{array}$ & $\begin{array}{l}.60 \\
.02\end{array}$ & $\begin{array}{l}.07 \\
.02\end{array}$ \\
\hline \multirow{4}{*}{ Curtis } & .01 & -.002 & .02 & .00 & .05 & \multirow{4}{*}{ Ryerson } & .01 & .001 & .00 & .97 & .12 \\
\hline & .01 & $-.02+$ & .56 & .00 & .01 & & .01 & -.01 & .00 & .00 & .04 \\
\hline & .10 & -.02 & .02 & .00 & .02 & & .10 & $.03 *$ & .00 & .98 & .02 \\
\hline & .10 & $-.01 *$ & .00 & .00 & .01 & & .10 & -.01 & .00 & .00 & .02 \\
\hline \multirow{4}{*}{ Douglas } & .01 & -.01 & .02 & .01 & .24 & \multirow{4}{*}{ Santa Fe } & .01 & -.01 & .01 & .32 & .13 \\
\hline & .01 & -.02 & .00 & .04 & .03 & & .01 & $-.02 *$ & .00 & .01 & .08 \\
\hline & .10 & $.02 @$ & .01 & .01 & .04 & & .10 & .03 & .02 & .23 & .02 \\
\hline & .10 & -.01 & .00 & .04 & .03 & & .10 & -.01 & .00 & .01 & .01 \\
\hline \multirow{4}{*}{ ESB } & .01 & $.01 @$ & .01 & .00 & .10 & \multirow{4}{*}{ Seabord } & .01 & .03 & .02 & .71 & .17 \\
\hline & .01 & .002 & .00 & .00 & .01 & & .01 & -.01 & .00 & .25 & .03 \\
\hline & .10 & $.03 *$ & .01 & .00 & .01 & & .10 & $.04 *$ & .87 & .70 & .01 \\
\hline & .10 & .01 & .00 & .00 & .01 & & .10 & -.01 & .00 & .30 & .004 \\
\hline \multirow{4}{*}{ Exxon Mobil } & .01 & -.003 & .03 & .44 & .27 & \multirow{4}{*}{ Spartans } & .01 & -.01 & .87 & .26 & .25 \\
\hline & .01 & $-.02 *$ & .17 & .05 & .05 & & .01 & $-.03 *$ & .00 & .06 & .12 \\
\hline & .10 & -.04@ & .03 & .48 & .08 & & .10 & .01 & .83 & .25 & .14 \\
\hline & .10 & -.00 & .18 & .09 & .01 & & .10 & $-.04 *$ & .00 & .05 & .04 \\
\hline \multirow{4}{*}{ Ford } & .01 & -.02 & .42 & .50 & .18 & \multirow{4}{*}{ U. Carbide } & .01 & $.008+$ & .00 & .73 & .04 \\
\hline & .01 & $-.03+$ & .00 & .00 & .18 & & .01 & -.003 & .00 & .00 & .06 \\
\hline & .10 & $-.12 *$ & .46 & .45 & .04 & & .10 & .03 & .00 & .70 & .02 \\
\hline & .10 & $-.03 *$ & .00 & .00 & .05 & & .10 & .003 & .00 & .00 & .04 \\
\hline \multirow{4}{*}{ GE } & .01 & .00 & .20 & .00 & .15 & \multirow{4}{*}{ Unisys } & .01 & $-.09+$ & .48 & .74 & .34 \\
\hline & .01 & 0.01 & .24 & .01 & .07 & & .01 & $-.10 *$ & .00 & .00 & .26 \\
\hline & .10 & $-.03 *$ & .24 & .00 & .03 & & .10 & $-.04+$ & .42 & .60 & .08 \\
\hline & .10 & $-.02 *$ & .26 & .00 & .04 & & .10 & $-.03+$ & .00 & .00 & .06 \\
\hline \multirow{4}{*}{ Gen Amer } & .01 & -.07@ & .43 & .01 & .25 & \multirow{4}{*}{ U. Pacific } & .01 & .005 & .00 & .13 & .11 \\
\hline & .01 & $-.09+$ & .00 & .00 & .03 & & .01 & -.01@ & .00 & .00 & .06 \\
\hline & .10 & -.05 & .42 & .01 & .04 & & .10 & $.02 *$ & .00 & .17 & .01 \\
\hline & .10 & $-.07+$ & .01 & .00 & .01 & & .10 & -.005 & .00 & .00 & .01 \\
\hline \multirow{2}{*}{ Globe } & .01 & -.01 & .00 & .03 & .24 & \multirow{2}{*}{ US Steel } & .01 & -.02 & .55 & .07 & .23 \\
\hline & .01 & $-.02+$ & .00 & .00 & .05 & & .01 & $-.03+$ & .04 & .01 & .08 \\
\hline
\end{tabular}




\begin{tabular}{|c|c|c|c|c|c|c|c|c|c|c|c|}
\hline & $\begin{array}{l}.10 \\
.10\end{array}$ & $\begin{array}{l}.02+ \\
-.01\end{array}$ & $\begin{array}{l}.00 \\
.00\end{array}$ & $\begin{array}{l}.06 \\
.00\end{array}$ & $\begin{array}{c}.04 \\
.003\end{array}$ & & $\begin{array}{l}.10 \\
.10\end{array}$ & $\begin{array}{c}-.03 \\
-.01 *\end{array}$ & $\begin{array}{l}.57 \\
.05\end{array}$ & $\begin{array}{l}.05 \\
.03\end{array}$ & $\begin{array}{l}.06 \\
.03\end{array}$ \\
\hline \multirow{4}{*}{ GM } & .01 & -.01 & .12 & .11 & .18 & \multirow{4}{*}{ Westinghouse } & .01 & -.00 & .06 & .34 & .11 \\
\hline & .01 & $-.02 *$ & .00 & .01 & .26 & & .01 & -.01 & .00 & .00 & .01 \\
\hline & .10 & $-.13 *$ & .11 & .10 & .09 & & .10 & $.03 *$ & .04 & .42 & .003 \\
\hline & .10 & $-.03 *$ & .00 & .01 & .09 & & .10 & -.003 & .00 & .00 & .004 \\
\hline \multirow{4}{*}{ Granite } & .01 & & & & & \multirow{4}{*}{ Xerox } & .01 & & & & .18 \\
\hline & .01 & $\begin{array}{l}.001 \\
-.02+\end{array}$ & .00 & $\begin{array}{l}.11 \\
00\end{array}$ & .05 & & .01 & $\begin{array}{l}-.02 \\
-.01\end{array}$ & .00 & .08 & .16 \\
\hline & .10 & $.03 *$ & .00 & .17 & .01 & & .10 & -.00 & 00 & 11 & .08 \\
\hline & .10 & $-.01+$ & .00 & .00 & .02 & & .10 & $-.02 *$ & .00 & .06 & .03 \\
\hline \multirow{4}{*}{ Kodak } & .01 & .01 & .01 & .97 & .15 & \multirow{4}{*}{ Zenith } & .01 & -.03 & .78 & .02 & .31 \\
\hline & .01 & -.01@ & .00 & .00 & .36 & & .01 & -.04 & .00 & .00 & .08 \\
\hline & .10 & -.04 & -.04 & .98 & .03 & & .10 & $.04+$ & .81 & .02 & .08 \\
\hline & .10 & $-.02 *$ & $-.02 *$ & .00 & .12 & & .10 & $-.05+$ & .00 & .00 & .03 \\
\hline
\end{tabular}

Note: $\tau$ refers to the quantiles estimated. $\theta_{4}$ is the coefficient on the dummy variable for the Great Depression (Oct. 23-

Nov. 14, 1929), Cuban Missile Crisis (Oct. 16-28, 1962), and the Global Financial Crisis (Aug. 4-Oct. 9. 2008). Significance levels are as in Table 2. SET is the p-value for the Wald test of slope equality (i.e., whether $\tau=.01$ is statistically different from $\tau=.10$ ). SQT is the Wald test for whether coefficient estimates for $\tau=.01, .10, .90, .99$ are symmetric. The appendix contains more details about the individual stocks. 
Figure 1A: Stock Price Indexes in the US, Canada, and Mexico 1960-1965

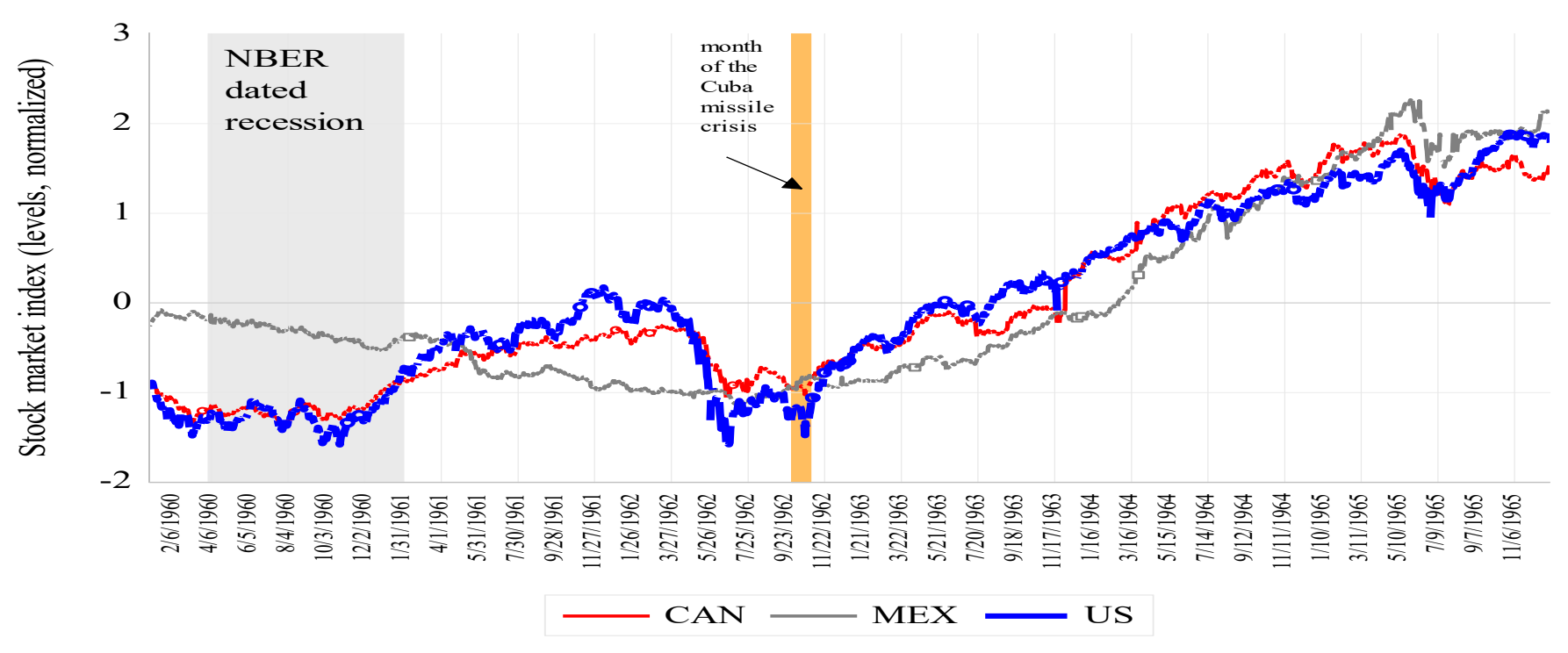


Figure 1B: Stock Price indexes in the US, Canada, and Mexico During 1962

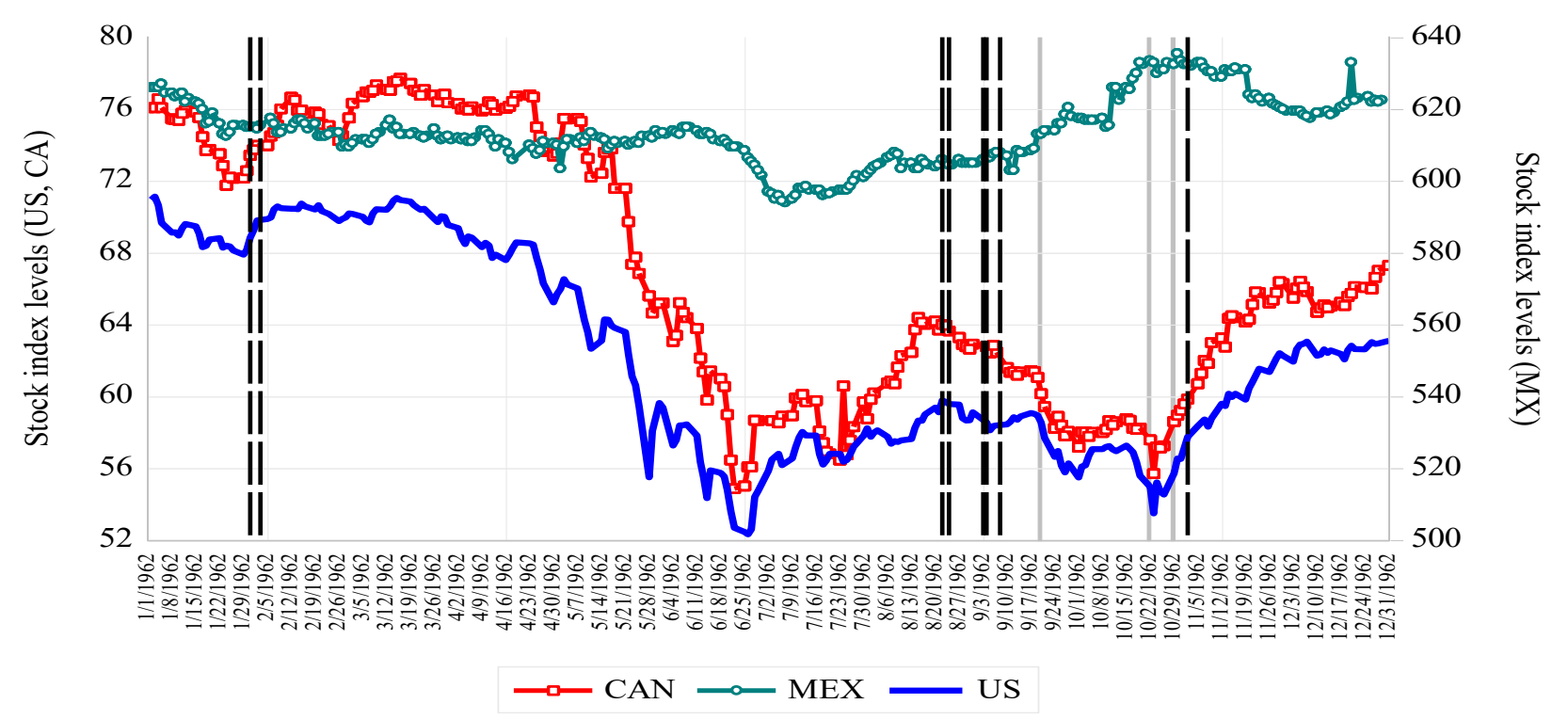

Note: Vertical dashed lines indicate events highlighted in the chronology of events. See the Appendix. Data sources are given in the text. 
Figure 1C: Performance of US vs. Canadian and Mexican Stock Markets During 1962

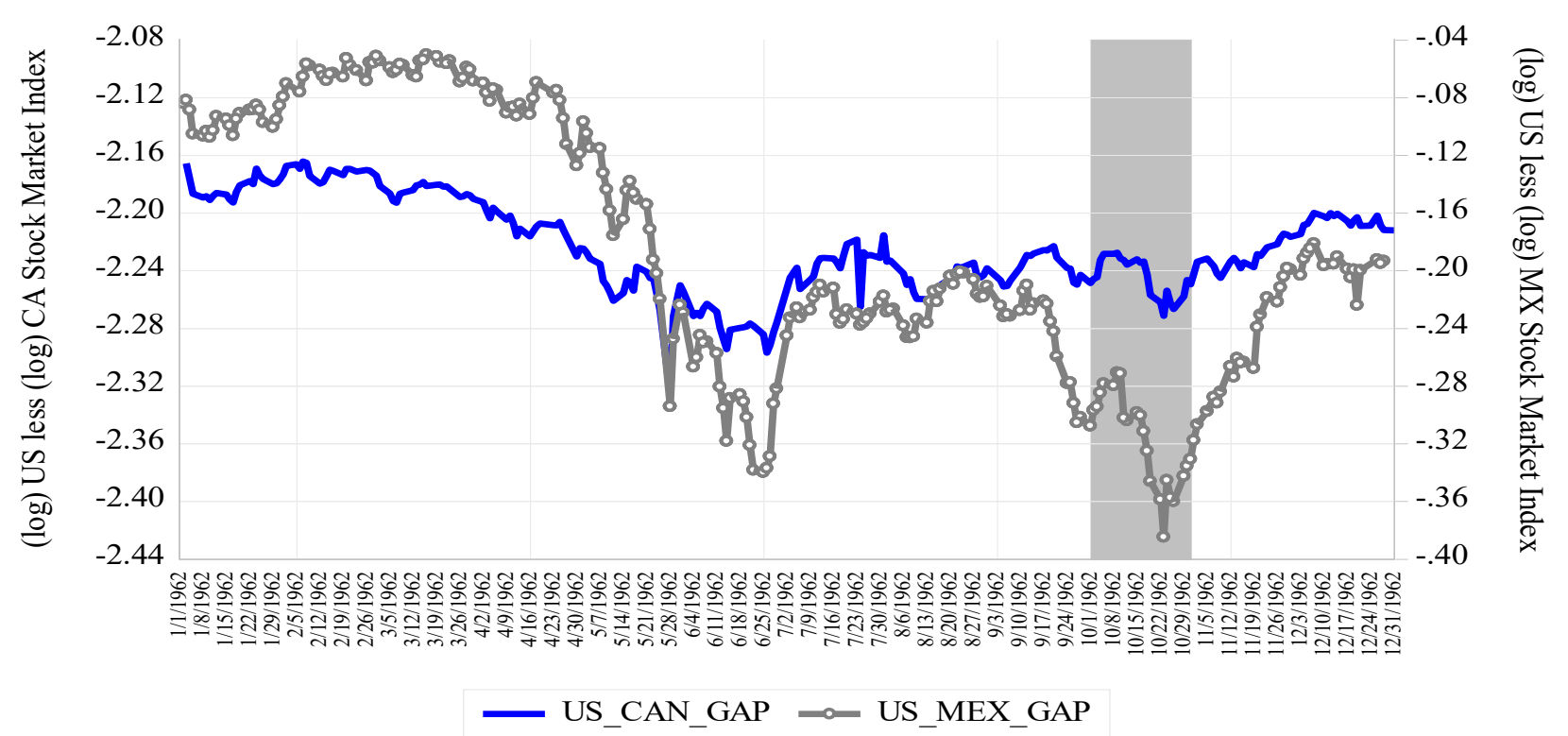

Note: The shaded area highlights the October 1962 (entire month not the '13 days') crisis period. 
Figure 2: Return Performance in a Selection of Stocks on the NYSE During the Thirteen Days
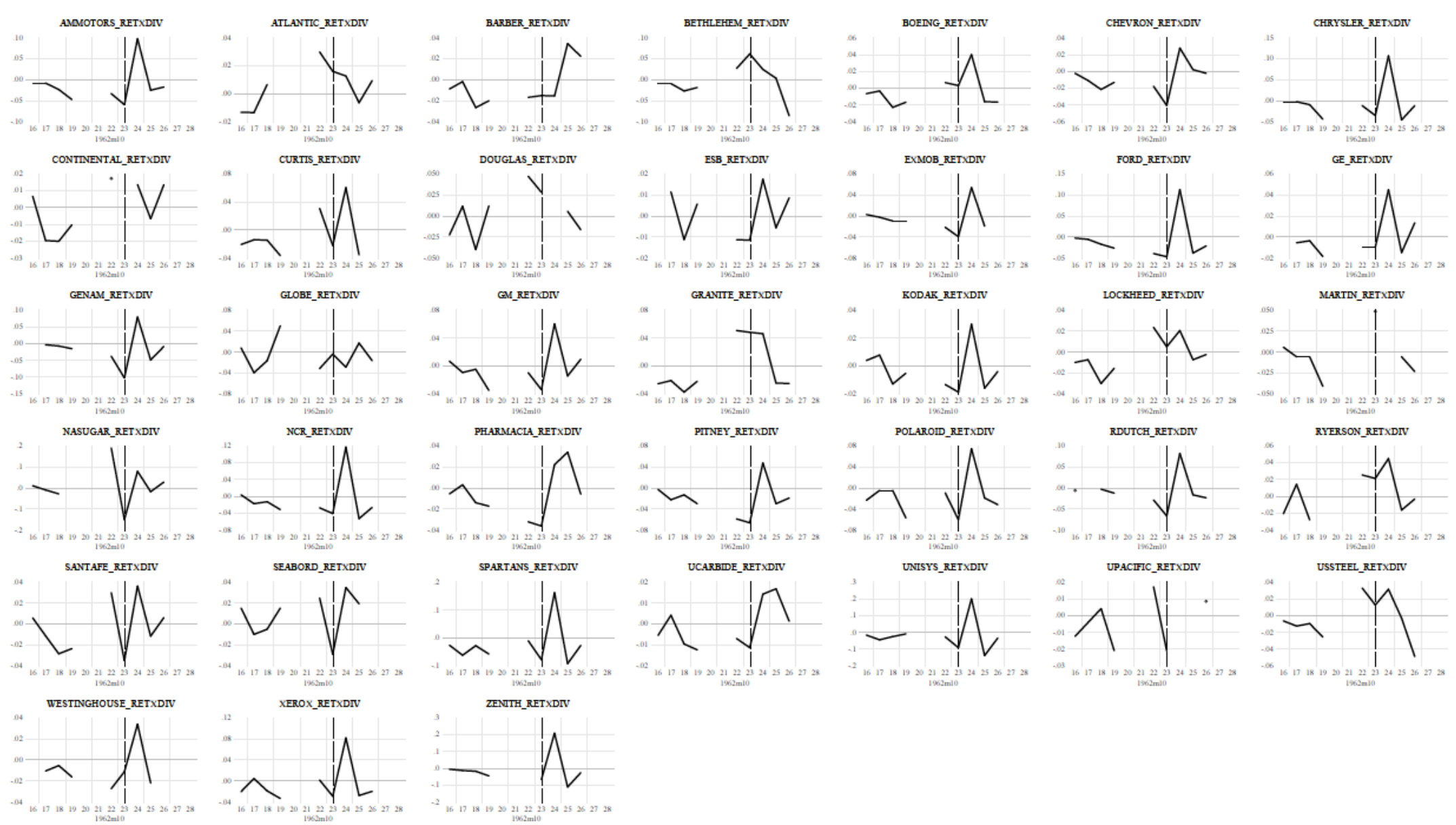

Note: See the appendix for more details about the stocks sampled. RETXDIV means return excluding dividends. The vertical dashed line is the day of President Kennedy's address to the nation (October 22 $\left.2^{\text {nd }}, 1962\right)$. Gaps refer to non-trading days or where no price data are recorded. Data are from CRSP (Center for Research in Security Prices). 


\section{Figure 3: The Behavior of US Interest Rate Spreads 1962-1965}

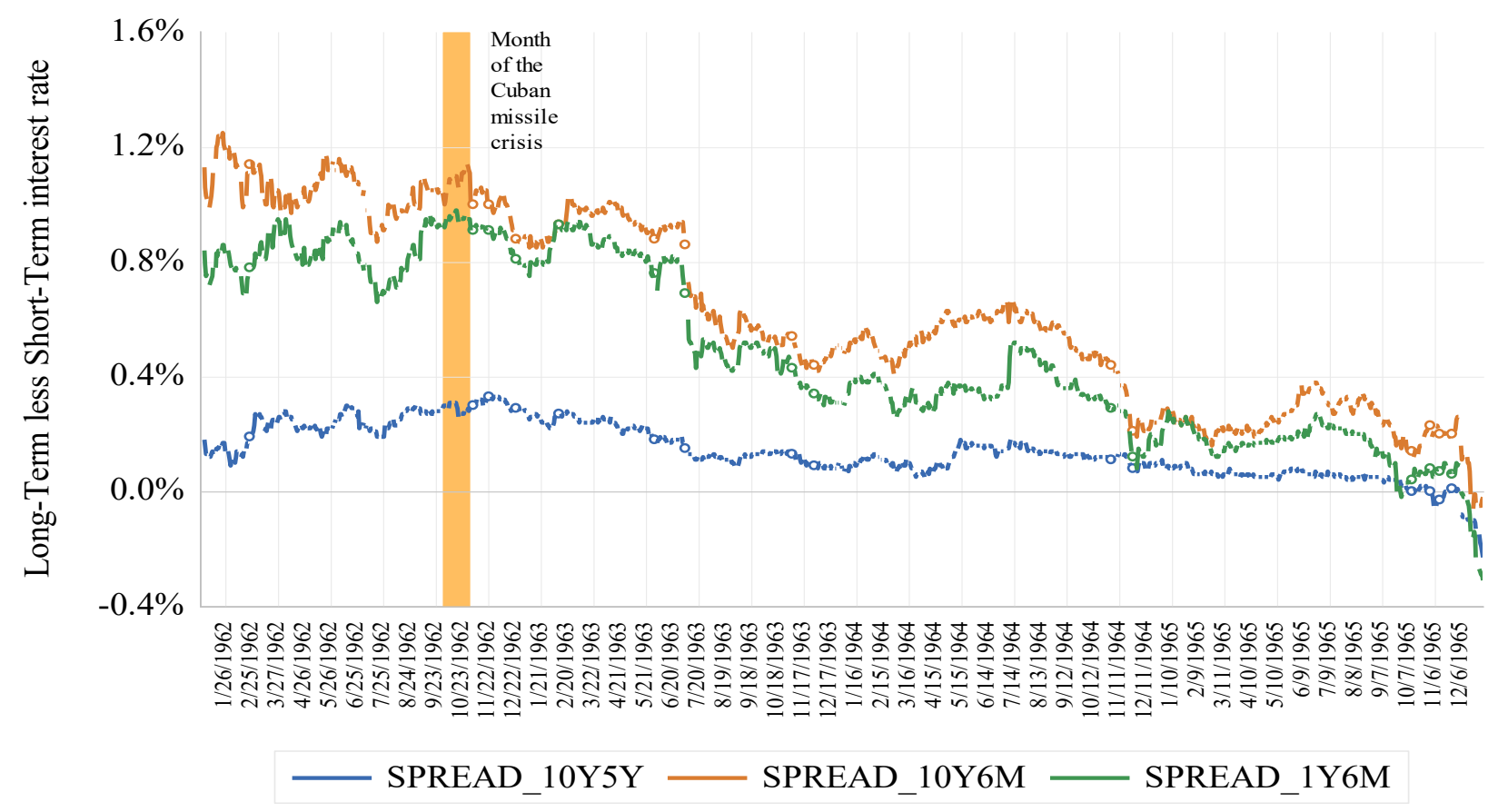

Note: 10Y5Y, 10Y6M, and 1Y6M, respectively, refer to the spread between US 10-year Treasury notes (10Y) vs. 5-year notes (5Y), one year T-bills (1Y), and six month T-bills (6M). Data from CRSP and FRED (Federal Reserve Bank of St. Louis). 
Figure 4: Commodity Price Behavior Around the Time of the Cuban Missile Crisis
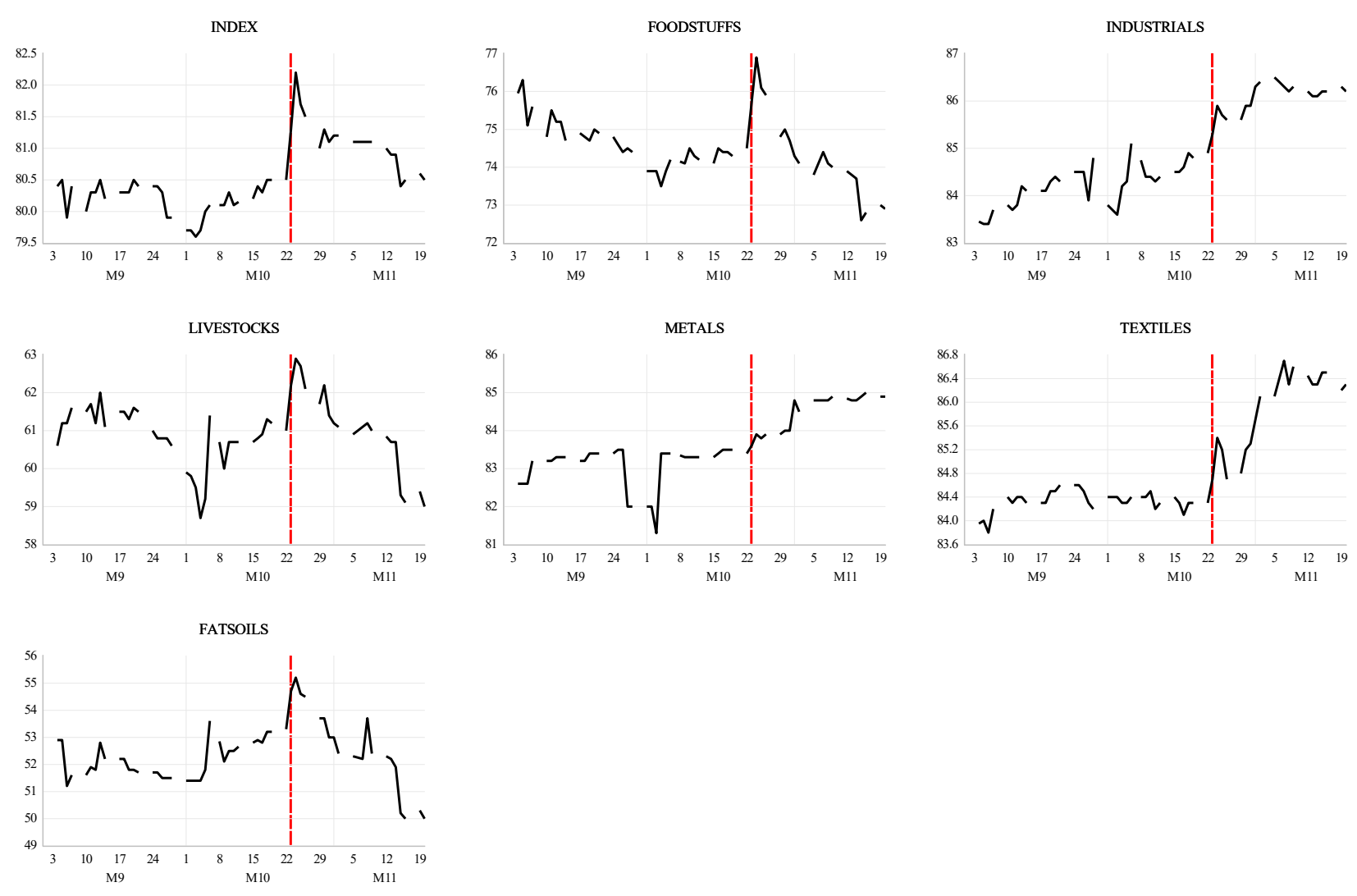

Note: Data as reported in daily issues of the New York Times. 
Figure 5: Volatility in US Stock Returns

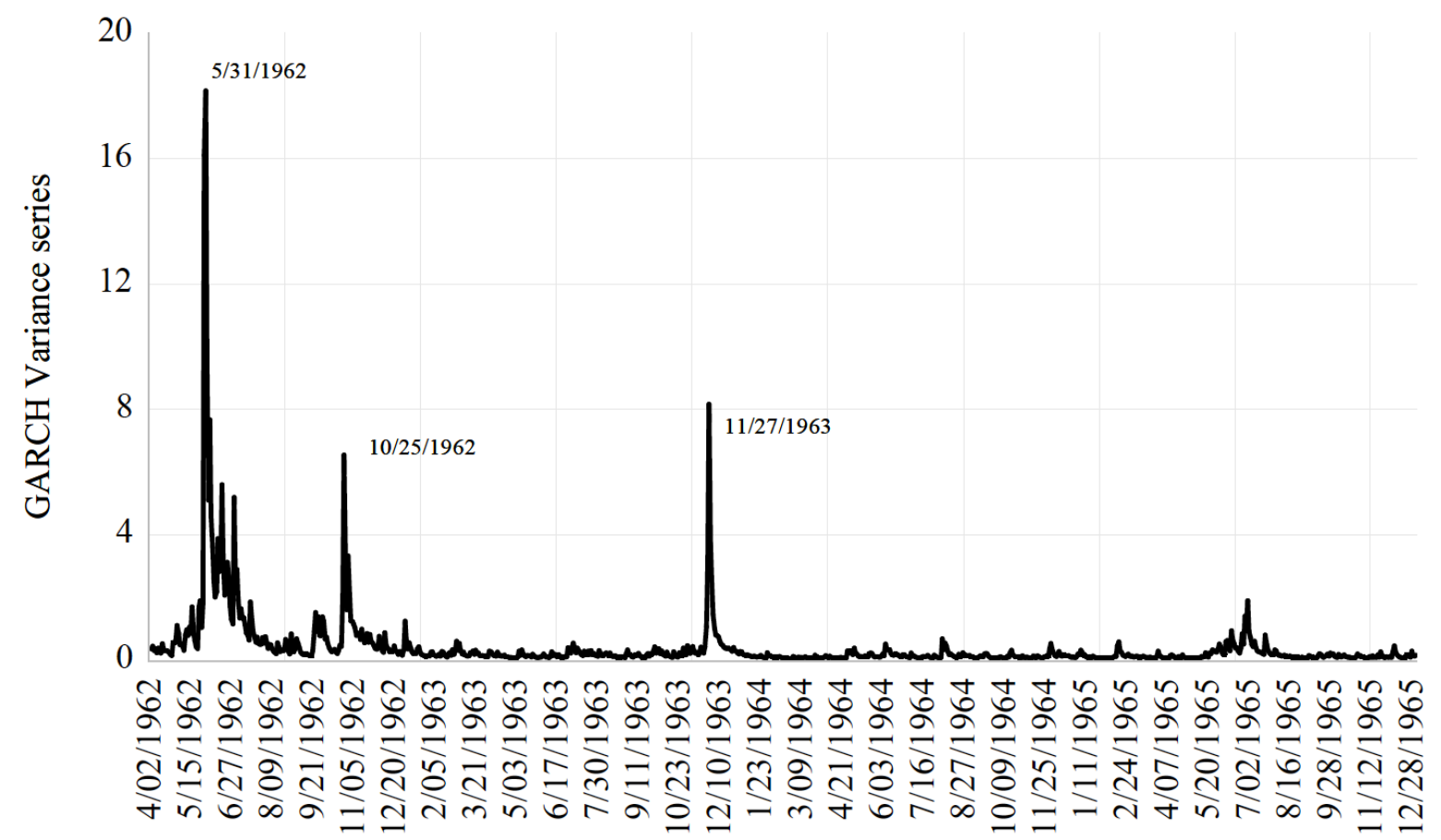

Note: Daily GARCH volatility series from the CGARH(1,1) estimates in Table 3. 


\section{APPENDIX}

Selective Chronology of 1962 Crisis Events

\begin{tabular}{|c|c|}
\hline 31 January 1962 & OAS excludes Cuba \\
\hline February 31962 & Cuba trade embargo announced \\
\hline August 221962 & $\begin{array}{l}\text { CIA warns that Soviet Union may try to } \\
\text { introduce missiles into Cuba }\end{array}$ \\
\hline August 241962 & $\begin{array}{l}\text { State department press briefing on military } \\
\text { build-up in Cuba }\end{array}$ \\
\hline September 31962 & Soviet - Cuba arms agreement announced \\
\hline September 41962 & $\begin{array}{l}\text { JFK publicly announces "whatever means } \\
\text { necessary" to counter Soviet 'aggression' }\end{array}$ \\
\hline September 81962 & $1^{\text {st }}$ ICBMs reach Cuba \\
\hline 19-20 September 1962 & $\begin{array}{c}\text { HR approves resolution of use of force } \\
\text { against Cuba }\end{array}$ \\
\hline September 211962 & USSR warns of potential for war \\
\hline October 2-3 1962 & $\begin{array}{l}\text { OAS meeting (in camera) and subsequent } \\
\text { communiqué outlines grave concerns }\end{array}$ \\
\hline October 81962 & $\begin{array}{l}\text { US withholds economic aid from countries } \\
\text { trading with Cuba }\end{array}$ \\
\hline October 181962 & $\begin{array}{l}\text { Kennedy meets with foreign minister } \\
\text { Gromyko }\end{array}$ \\
\hline October 211962 & Cuba 'blockade' leaks in NYT \\
\hline October 221962 & $\begin{array}{l}\text { Kennedy speaks to the nation and the world } \\
\text { US forces placed on DEFCON3 } \\
\text { Diefenbaker in Canada declines to follow suit } \\
\text { Crisis becomes public }\end{array}$ \\
\hline October 231962 & $\begin{array}{l}\text { Announcement of interdiction of the delivery } \\
\text { of offensive weapons to Cuba } \\
\text { US media criticizes Canada (but Canada's } \\
\text { foreign affairs minister Harkness discretely } \\
\text { places military on alert) }\end{array}$ \\
\hline October 251962 & Diefenbaker states support for US \\
\hline October 281962 & US suspends Cuba blockade \\
\hline October 291962 & UN to appoint inspectors \\
\hline October 29 - November 41962 & Soviet forces withdraw from Cuba \\
\hline November 21962 & $\begin{array}{c}\text { Kennedy makes statement about lack of } \\
\text { progress in removing offensive weapons from } \\
\text { Cuba }\end{array}$ \\
\hline November 61962 & Canadian forces return to normal operations \\
\hline
\end{tabular}

Source: from references provided in section 2 
Table A1: Largest Drops in Daily Stock Returns: US, Canada, and Mexico 1962-1965

U.S.

$\begin{array}{cc}5 / 28 / 1962 & -6.68 \\ 6 / 04 / 1962 & -3.55 \\ 11 / 22 / 1963 & -2.81 \\ \mathbf{1 0} / \mathbf{2 3} / \mathbf{1 9 6 2} & -2.67 \\ 6 / 12 / 1962 & -2.56 \\ 9 / 19 / 1960 & -2.271 \\ 6 / 21 / 1962 & -2.17 \\ 6 / 14 / 1962 & -2.11 \\ 4 / 24 / 1961 & -2.08 \\ 5 / 23 / 1962 & -1.97 \\ 5 / 22 / 1962 & -1.97 \\ 5 / 25 / 1962 & -1.90 \\ 9 / 24 / 1962 & -1.84 \\ 7 / 17 / 1962 & -1.82 \\ 6 / 28 / 1965 & -1.76 \\ 6 / 22 / 1962 & -1.70 \\ 4 / 30 / 1962 & -1.60 \\ 9 / 26 / 1960 & -1.56\end{array}$

$\begin{array}{lr} & \\ \text { 3/30/1964 } & \\ 7 / 25 / 1962 & -4.08 \\ 7 / 18 / 1963 & -3.53 \\ 6 / 21 / 1962 & -2.42 \\ 6 / 28 / 1965 & -2.37 \\ 5 / 23 / 1962 & -2.24 \\ 11 / 22 / 1963 & -2.02 \\ \text { 9/22/1960 } & -1.99 \\ 6 / 04 / 1962 & -1.93 \\ 5 / 18 / 1962 & -1.90 \\ 6 / 14 / 1965 & -1.82 \\ \mathbf{1 0 / 2 3 / 1 9 6 2} & -1.80 \\ \mathbf{7 / 1 7 / 1 9 6 2} & \mathbf{- 1 . 7 8 0 5 3 2} \\ 5 / 22 / 1962 & -1.56 \\ \mathbf{6 / 2 2 / 1 9 6 2} & -1.54 \\ \mathbf{6} / 08 / 1965 & -1.52 \\ \mathbf{6 / 1 2 / 1 9 6 2} & -1.527 \\ 11 / 24 / 1964 & -1.47 \\ & -1.45\end{array}$

\begin{tabular}{ll}
\multicolumn{1}{c}{ Mexico } & \\
$8 / 03 / 1965$ & -3.56 \\
$7 / 13 / 1965$ & -3.36 \\
$4 / 30 / 1965$ & -3.23 \\
$12 / 20 / 1962$ & -2.80 \\
$10 / 11 / 1962$ & -2.72 \\
$6 / 11 / 1965$ & -2.59 \\
$8 / 10 / 1965$ & -2.38 \\
$8 / 07 / 1965$ & -2.28 \\
$4 / 06 / 1960$ & -1.96 \\
$8 / 06 / 1963$ & -1.95 \\
$6 / 30 / 1965$ & -1.92 \\
$4 / 26 / 1963$ & -1.79 \\
$3 / 24 / 1964$ & -1.68 \\
$8 / 17 / 1964$ & -1.65 \\
$5 / 03 / 1962$ & -1.62 \\
$4 / 08 / 1964$ & -1.50
\end{tabular}


9/13/1962

$3 / 20 / 1963$
$-1.49$

$-1.47$

Note: Daily stock returns are 100 times log first difference in stock market index levels. In bold (italics for Mexico) the daily return (ex dividends) the day following President Kennedy address to the nation. 
Table A2: List of Stocks Sampled from the NYSE

\begin{tabular}{|c|c|c|c|c|c|c|c|}
\hline NAME & SECTOR & Available Sample & $\mathrm{T}$ & $\begin{array}{l}\text { Largest } \\
\text { Drop } \\
\text { (Full) }\end{array}$ & $\begin{array}{l}\text { Largest } \\
\text { Drop } \\
\text { (CMC) }\end{array}$ & $\begin{array}{l}\text { Largest } \\
\text { Drop } \\
\text { (GD) }\end{array}$ & $\begin{array}{c}\text { Largest } \\
\text { Drop } \\
\text { (GFC) }\end{array}$ \\
\hline American Motors & Automotive & $\begin{array}{l}1925 / 12 / 31- \\
1987 / 08 / 05\end{array}$ & 12292 & 0.25 & 0.05 & 0.25 & \\
\hline Atlantic & Transport & $\begin{array}{l}1925 / 12 / 31- \\
1981 / 06 / 03\end{array}$ & 10220 & 0.33 & 0.01 & 0.04 & \\
\hline Barber & Petroleum & $\begin{array}{l}1925 / 12 / 31- \\
1967 / 12 / 30\end{array}$ & 13108 & 0.24 & 0.03 & 0.17 & \\
\hline Bethlehem & Steel (industrial) & $\begin{array}{l}\text { 1925/12/31- } \\
2002 / 06 / 11\end{array}$ & 18120 & 0.82 & 0.09 & 0.11 & \\
\hline Boeing & Aircraft & $\begin{array}{l}1934 / 09 / 05- \\
2018 / 12 / 31\end{array}$ & 20257 & 0.21 & 0.02 & & 0.08 \\
\hline Chevron & Petroleum & $\begin{array}{l}1925 / 12 / 31- \\
2018 / 12 / 31\end{array}$ & 22416 & 0.17 & 0.04 & 0.06 & 0.12 \\
\hline Chrysler & Automotive & $\begin{array}{l}\text { 1925/12/31- } \\
1998 / 11 / 12\end{array}$ & 17684 & 0.18 & 0.05 & 0.16 & \\
\hline Continental & Steel (industrial) & $\begin{array}{l}1936 / 04 / 07- \\
1973 / 05 / 11\end{array}$ & 8265 & 0.26 & 0.02 & & \\
\hline Curtis-Wright & $\begin{array}{c}\text { Defense } \\
\text { (industrial) }\end{array}$ & $\begin{array}{l}1929 / 08 / 22- \\
2018 / 12 / 31\end{array}$ & 18782 & 0.44 & 0.04 & 0.27 & 0.09 \\
\hline Douglas & Aircraft & $\begin{array}{l}1931 / 06 / 25- \\
1967 / 08 / 08\end{array}$ & 8948 & 0.27 & 0.04 & & \\
\hline ESB & Energy & $\begin{array}{l}1925 / 12 / 31- \\
1974 / 09 / 03\end{array}$ & 11224 & 0.29 & 0.01 & 0.29 & \\
\hline Exxon-Mobil & Petroleum & $\begin{array}{l}\text { 1925/12/31- } \\
\text { 2019/12/31 }\end{array}$ & 22510 & 0.23 & 0.04 & 0.11 & \\
\hline Ford & Automotive & $\begin{array}{l}\text { 1956/03/07- } \\
2018 / 12 / 31\end{array}$ & 14572 & 0.25 & 0.05 & & \\
\hline $\begin{array}{l}\text { General Electric } \\
\text { (GE) }\end{array}$ & $\begin{array}{l}\text { Manufacturer } \\
\text { (industrial) }\end{array}$ & $\begin{array}{l}1925 / 12 / 31- \\
2018 / 12 / 31\end{array}$ & 22800 & 0.20 & 0.02 & 0.16 & \\
\hline General American & Petroleum & $\begin{array}{l}1957 / 04 / 24- \\
1983 / 03 / 08\end{array}$ & 5760 & 0.14 & 0.10 & & \\
\hline Globe Union & Industrial & $\begin{array}{l}1962 / 07 / 02- \\
1978 / 10 / 10\end{array}$ & 3377 & 0.18 & 0.04 & & \\
\hline
\end{tabular}




\begin{tabular}{|c|c|c|c|c|c|c|c|}
\hline $\begin{array}{c}\text { General Motors } \\
\text { (GM) }\end{array}$ & Automotive & $\begin{array}{l}\text { 1925/12/31- } \\
2009 / 06 / 01\end{array}$ & 20501 & 0.33 & 0.03 & 0.16 & 0.31 \\
\hline Granite & $\begin{array}{l}\text { Construction } \\
\text { (industrial) }\end{array}$ & $\begin{array}{l}1929 / 06 / 01- \\
1971 / 08 / 13\end{array}$ & 9461 & 0.30 & 0.04 & 0.14 & \\
\hline (Eastman) Kodak & $\begin{array}{l}\text { Manufacturer } \\
\text { (industrial) }\end{array}$ & $\begin{array}{l}1925 / 12 / 31- \\
2012 / 01 / 18\end{array}$ & 21112 & 0.54 & 0.02 & 0.19 & \\
\hline Lockheed & Aircraft & $\begin{array}{l}\text { 1939/12/09- } \\
2018 / 12 / 31\end{array}$ & 18552 & 0.25 & 0.03 & & \\
\hline Martin Marietta & $\begin{array}{l}\text { Building } \\
\text { (industrial) }\end{array}$ & $\begin{array}{l}1937 / 04 / 26- \\
1995 / 03 / 05\end{array}$ & 12969 & 0.21 & 0.04 & 0.13 & \\
\hline $\begin{array}{l}\text { North American } \\
\text { (NA) Sugar }\end{array}$ & Sugar & $\begin{array}{l}1925 / 12 / 31- \\
1971 / 04 / 28\end{array}$ & 9516 & 0.33 & 0.15 & & \\
\hline NCR & $\begin{array}{l}\text { Manufacturer } \\
\text { (industrial) }\end{array}$ & $\begin{array}{l}1934 / 04 / 26- \\
1991 / 09 / 19\end{array}$ & 13577 & 0.15 & 0.05 & & \\
\hline Pharmacia & Chemicals & $\begin{array}{l}\text { 1929/10/10- } \\
2003 / 04 / 15\end{array}$ & 17606 & 0.27 & 0.04 & 0.15 & \\
\hline Pitney-Bowes & $\begin{array}{l}\text { Manufacturer } \\
\text { (industrial) }\end{array}$ & $\begin{array}{l}1950 / 09 / 18- \\
2018 / 12 / 31\end{array}$ & 15600 & 0.28 & 0.07 & & 0.07 \\
\hline Polaroid & $\begin{array}{l}\text { Manufacturer } \\
\text { (industrial) }\end{array}$ & $\begin{array}{l}1957 / 11 / 04- \\
2001 / 10 / 09\end{array}$ & 10364 & 0.35 & 0.06 & & \\
\hline Royal Dutch & Petroleum & $\begin{array}{l}1954 / 07 / 20- \\
2005 / 11 / 18\end{array}$ & 11830 & 0.22 & 0.07 & & \\
\hline Ryerson & Holding Co. & $\begin{array}{l}\text { 1925/12/31- } \\
2007 / 10 / 18\end{array}$ & 18942 & 0.31 & 0.03 & 0.11 & \\
\hline Santa Fe & Transport & $\begin{array}{l}1925 / 12 / 31- \\
1969 / 05 / 09\end{array}$ & 10797 & 0.14 & 0.03 & 0.11 & \\
\hline Seabord & Transport & $\begin{array}{l}1945 / 10 / 31- \\
1980 / 10 / 31\end{array}$ & 7829 & 0.30 & 0.03 & & \\
\hline Spartans & Industrial & $\begin{array}{l}1957 / 02 / 18- \\
1971 / 02 / 26\end{array}$ & 3086 & 0.17 & 0.09 & & \\
\hline Union Carbide & Chemicals & $\begin{array}{l}\text { 1926/03/01- } \\
\text { 2001/02/06 }\end{array}$ & 18110 & 0.19 & 0.01 & 0.19 & \\
\hline Unisys & $\begin{array}{l}\text { Information } \\
\text { Technology }\end{array}$ & $\begin{array}{l}\text { 1925/12/31- } \\
\text { 2018/12/31 }\end{array}$ & 21332 & 0.38 & 0.14 & 0.35 & 0.15 \\
\hline Union Pacific & Transport & $\begin{array}{l}1925 / 12 / 31- \\
1971 / 06 / 25\end{array}$ & 11117 & 0.10 & 0.02 & 0.08 & \\
\hline US Steel & Steel (industrial) & $\begin{array}{l}1925 / 12 / 31- \\
2018 / 12 / 31\end{array}$ & 22601 & 0.37 & 0.05 & 0.09 & 0.11 \\
\hline
\end{tabular}




\begin{tabular}{|c|c|c|c|c|c|c|c|}
\hline Westinghouse & $\begin{array}{c}\text { Manufacturer } \\
\text { (industrial) }\end{array}$ & $\begin{array}{c}1925 / 12 / 31- \\
1968 / 06 / 07\end{array}$ & 9953 & 0.16 & 0.03 & 0.15 & \\
\hline Xerox & $\begin{array}{c}\text { Manufacturer } \\
\text { (industrial) }\end{array}$ & $\begin{array}{c}1961 / 07 / 11- \\
2018 / 12 / 31\end{array}$ & 13876 & 0.26 & 0.03 & & 0.08 \\
\hline Zenith & Television & $1929 / 07 / 18-$ & 15666 & 0.69 & 0.11 & 0.34 & \\
& (industrial) & $1998 / 05 / 21$ & & & & & \\
\hline
\end{tabular}

Source: CRSP. Sample is yyyy/mm/dd. Since only declines are considered all values in the last 4 columns are negative. CMC is the Cuban Missile Crisis (Oct. 16-28, 1962); GD is the Great Depression (Oct. 23-Nov. 14, 1929); and the Global Financial Crisis (Aug. 4-Oct. 9, 2008). T is the total number of available observations. A blank means no data are available. The data refer to returns excluding dividends on a daily basis. 
Table A3: Top 10\% of Declines in Daily Stock Returns (ex dividends): 1962-1965

\begin{tabular}{|c|c|}
\hline NAME & $\%$ of $\mathrm{T}$ \\
\hline American Motors & 3.2 \\
\hline Atlantic & 2.3 \\
\hline Barber & 1.9 \\
\hline Bethlehem & 2.5 \\
\hline Boeing & 6.0 \\
\hline Chevron & 3.6 \\
\hline Chrysler & 7.0 \\
\hline Continental & 4.0 \\
\hline Curtis-Wright & 4.3 \\
\hline Douglas & 9.3 \\
\hline ESB & 4.2 \\
\hline Exxon-Mobil & 4.4 \\
\hline Ford & 4.7 \\
\hline General Electric (GE) & 6.1 \\
\hline General American & 6.8 \\
\hline Globe Union & 7.5 \\
\hline General Motors (GM) & 3.7 \\
\hline Granite & 3.9 \\
\hline (Eastman) Kodak & 4.2 \\
\hline Lockheed & 5.9 \\
\hline Martin Marietta & 7.1 \\
\hline North American (NA) Sugar & 3.8 \\
\hline NCR & 6.8 \\
\hline Pharmacia & 5.1 \\
\hline Pitney-Bowes & 11.3 \\
\hline Polaroid & 8.1 \\
\hline Royal Dutch & 6.1 \\
\hline
\end{tabular}




\begin{tabular}{|c|c|}
\hline Ryerson & 5.6 \\
\hline Santa Fe & 4.0 \\
\hline Seabord & 7.1 \\
\hline Spartans & 8.5 \\
\hline Union Carbide & 3.5 \\
\hline Unisys & 7.0 \\
\hline Union Pacific & 5.4 \\
\hline US Steel & 4.7 \\
\hline Westinghouse & 4.6 \\
\hline Xerox & 11.2 \\
\hline Zenith & 2.9 \\
\hline
\end{tabular}

Note: The table shows, as a percent of all observations for the Jan. 4,1962/- Dec. 31, 1965 sample, the fraction of the $10 \%$ largest drops in daily stock returns (ex dividends). 


\section{Table A4: The Doomsday Clock}

\begin{tabular}{|c|c|}
\hline Year & Minutes Before Midnight \\
\hline 1947 & 7 \\
\hline 1949 & 3 \\
\hline 1953 & 2 \\
\hline 1960 & 7 \\
\hline 1963 & 12 \\
\hline 1968 & 7 \\
\hline 1969 & 10 \\
\hline 1972 & 12 \\
\hline 1974 & 9 \\
\hline 1980 & 7 \\
\hline 1981 & 4 \\
\hline 1984 & 3 \\
\hline 1988 & 6 \\
\hline 1990 & 10 \\
\hline 1991 & 17 \\
\hline 1995 & 14 \\
\hline 1998 & 9 \\
\hline 2002 & 7 \\
\hline 2007 & 5 \\
\hline 2010 & 6 \\
\hline 2012 & 5 \\
\hline 2015 & 3 \\
\hline 2016 & 3 \\
\hline 2017 & 2.5 \\
\hline 2018 & 2 \\
\hline 2019 & 2 \\
\hline 2020 & 1.4 \\
\hline
\end{tabular}

Source: Bulletin of the Atomic Scientists "Doomsday Clock" [https://thebulletin.org/doomsdayclock/current-time/\#clock-timeline] 
Figure A1: Aggregate Returns Around the Time of President Kennedy's Address to the Nation

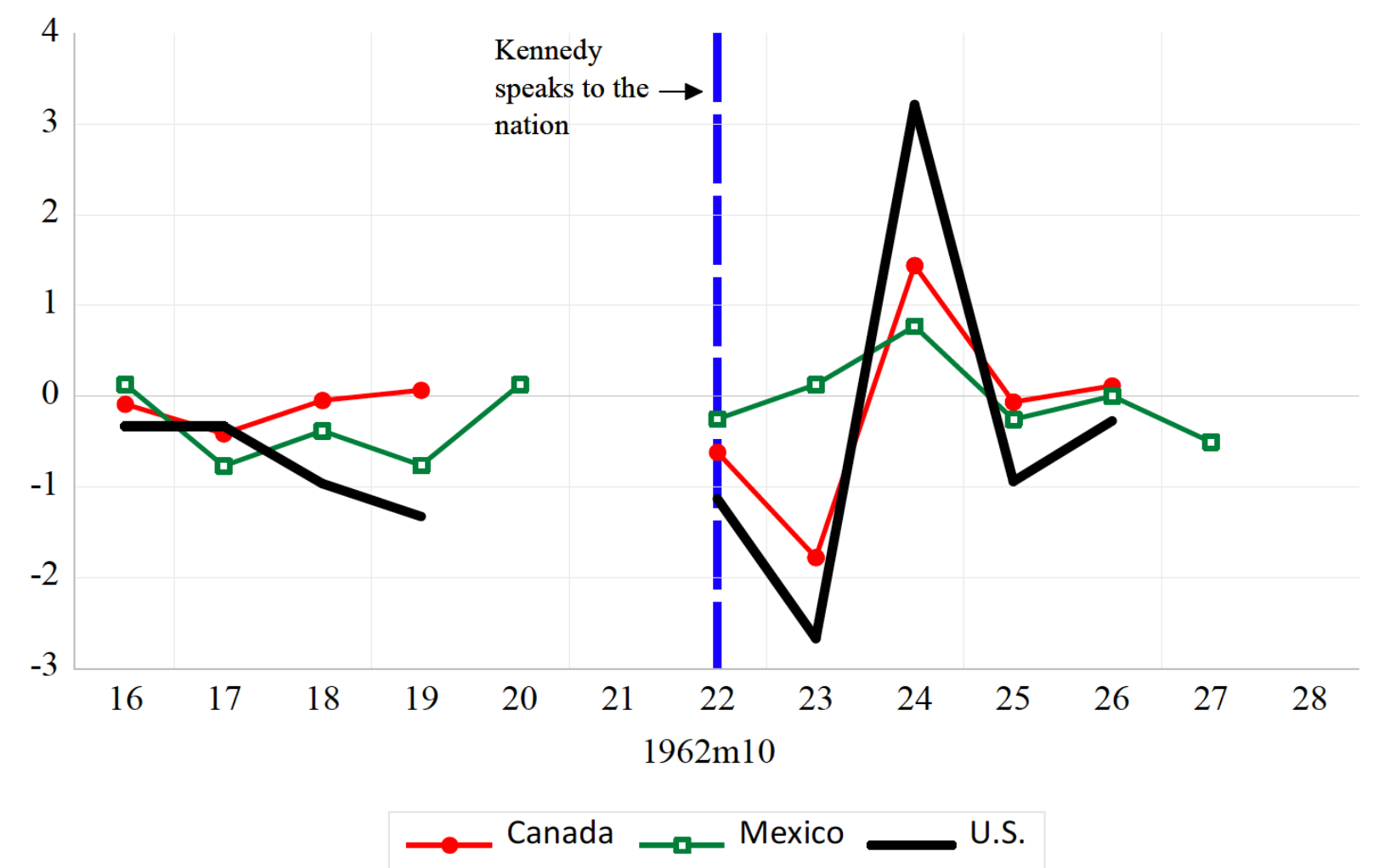

Source: Data source listed in the main text. Returns are ex dividends. The vertical axis is in percent. No trading on October 20-21, 1962. 
Figure A2: World Wide Nuclear Testing: 1945-2018

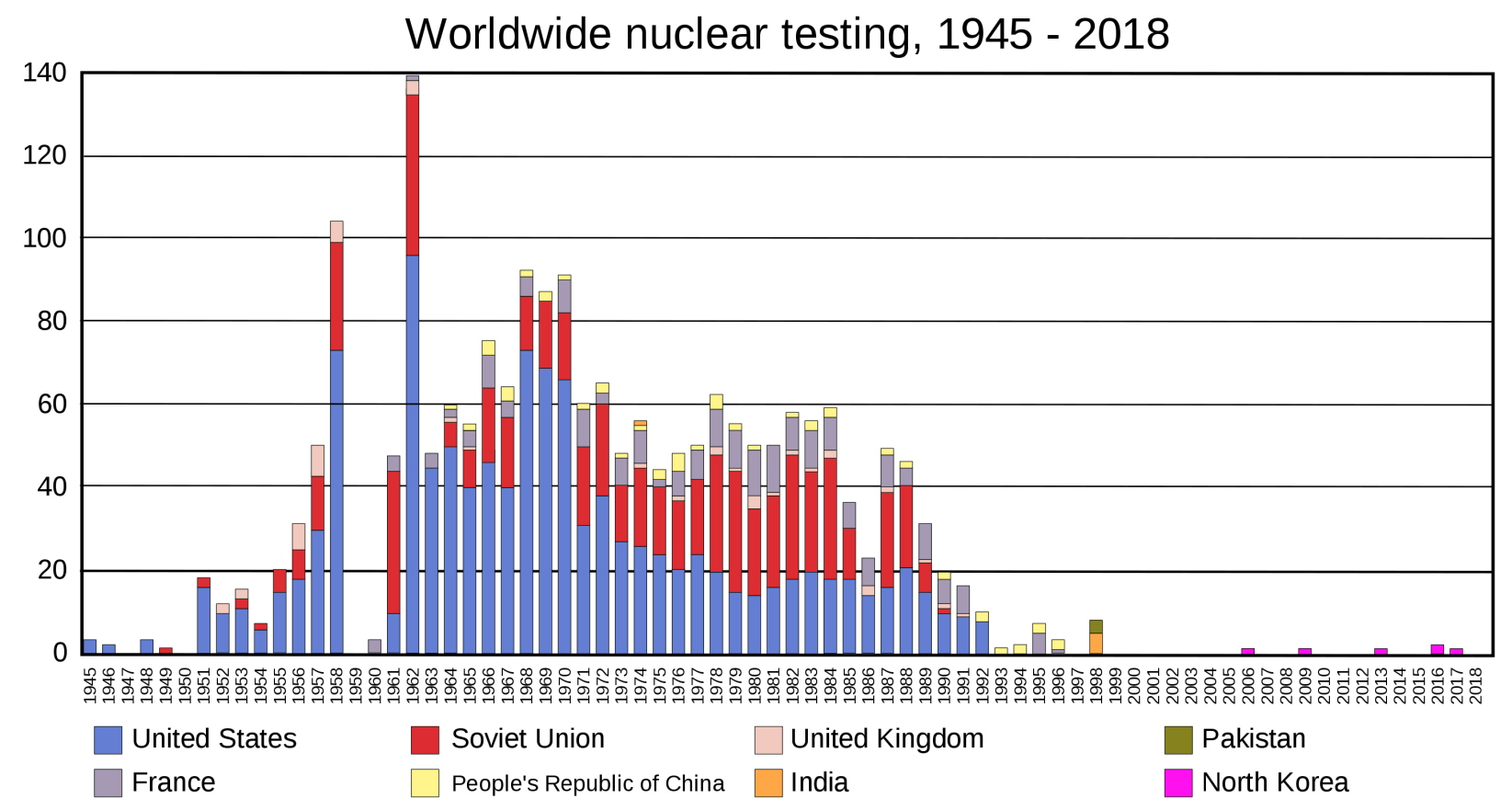

Source: By Worldwide nuclear testing.svg: Source: Oklahoma Geological Survey Nuclear Explosion Catalog - This file was derived from: Worldwide nuclear testing.svg, CC BY-SA 2.5, https://commons.wikimedia.org/w/index.php?curid=65809060. 
Figure A3: Commodity Prices, 1960-1965
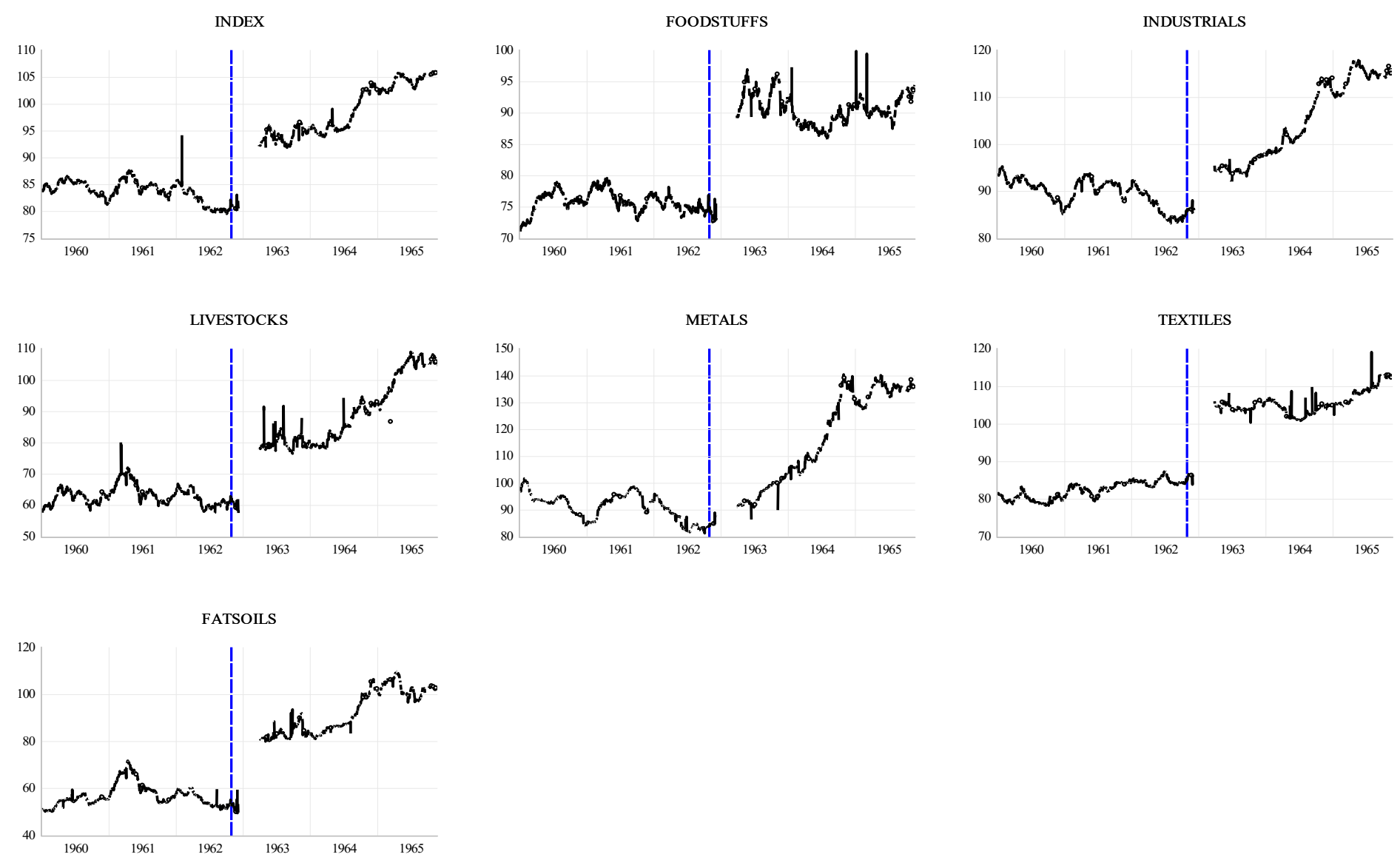

Note: Gap is due to lack of data. The vertical dashed line marks the day following President Kennedy's evening speech to the nation and the world. See the main text for data sources and details. 